\title{
CUANDO EL PROYECTO SE HACE MÉTODO: \\ NUEVAS PERSPECTIVAS PARA LA INVESTIGACIÓN SOCIOEDUCATIVA EN RED ${ }^{1}$
}

\author{
WHEN THE PROJECT BECOMES METHOD: \\ NEW PERSPECTIVES FOR NETWORK-BASED SOCIO-EDUCATIONAL RESEARCH
}

\section{QUANDO O PROJETO SE TORNA MÉTODO: NOVAS PERSPETIVAS PARA A INVESTIGAÇÃO SOCIOEDUCATIVA EM REDE}

\author{
José Antonio Caride Gómez \\ Universidad de Santiago de Compostela, España \\ Raúl Fraguela-Vale \\ UNIVERSIDAD DE A CORUÑA, ESPAÑA
}

RESUMEN: El artículo sitúa sus argumentos en el giro epistemológico que aportan a las Ciencias Sociales y de la Educación los denominados métodos mixtos. No solo como un modo de ampliar las expectativas que generan en la reflexión y la acción socioeducativa, sino también en los procesos de cambio y transformación social. Con estos supuestos, se presenta la Red de grupos de investigación OcioGune y el proyecto coordinado "De los tiempos educativos a los tiempos sociales: la construcción cotidiana de la condición juvenil en una sociedad de redes" (RESORTES). Una concreción práctica de las potencialidades inherentes al trabajo colaborativo y la mirada multi-interdisciplinar que aportan los saberes compartidos: un modo, entre otros, de agrandar las fronteras del conocimiento y de su transferencia a la sociedad haciendo uso de metodologías mixtas de investigación.

PALABRAS CLAVE: Tiempos educativos y sociales; investigación socioeducativa; trabajo en red; métodos mixtos; triangulación metodológica.

ABSTRACT: This paper centers its arguments in the epistemological shift that the so-called mixed methods have provided the Social and Educational Sciences with. It is not just as a way for widening the expectations they generate in socio-educational action and reflection but also in the change processes and social transformation. Based on these assumptions it is introduced the Network of Research Groups OcioGune and the coordinated project "From Educational to Social Times: the Daily Building of the Young Condition into a Network Society" (RESORTES). A practical realization of the potentialities inherent to collaborative work and the multidisciplinary approach provided by shared knowledge: 
a way, among others, to extend the frontiers of knowledge and its transfer to society by using mixed methods research.

KEYWORDS: Educational and social times; socio-educational research; networking; mixed methods; methodological triangulation.

RESUMO: O artigo aborda a relevância epistemológica dos denominados métodos mistos nas Ciências Sociais e da Educação. Não só como um modo de ampliar as expetativas metodológicas que se geram na reflexão e na ação socioeducativa, mas também nos processos de mudança e transformação social. É com base nestes pressupostos que se apresenta a Rede de grupos de investigação OcioGune e o projeto "Dos tempos educativos aos tempos sociais: a construção quotidiana da condição juvenil numa sociedade de redes"(RESORTES). Uma concretização prática das potencialidades inerentes ao trabalho colaborativo e um olhar multi-interdisciplinar fruto dos saberes partilhados: um modo, entre outros, de alargar as fronteiras do conhecimento e da sua transferência à sociedade, fazendo uso das metodologias mistas de investigação.

PALAVRAS-CHAVE: Tempos educativos e sociais; investigação socioeducativa; trabalho em rede; metodologias mistas; triangulação metodológica.

\section{Introducción}

La utilización de métodos mixtos de investigación está comenzando a consolidarse como un nuevo movimiento metodológico, tratando se superar el viejo dualismo establecido en torno a lo cuantitativo versus cualitativo (López-Fernández \& Molina-Azorín, 2011). Según Povee \& Roberts (2015), son tres los motivos que explican la importancia que está adquiriendo esta perspectiva de investigación en los últimos años: en primer lugar, la creciente permeabilidad de las comunidades científicas a sus respectivos modos de conocer y actuar, abriéndose a un diálogo paradigmático cada vez más fluido e integrador; en segundo término, el progresivo incremento de la publicación -ya desde los años noventa del pasado siglo- de trabajos que han dotado a este campo de un lenguaje propio, contribuyendo a renovar la formación de los investigadores interesados en la pluralidad metodológica; finalmente, el notable aumento que se registra en la edición de artículos en revistas científicas que hacen uso de metodologías mixtas.

Su extensión y popularidad en las Ciencias Sociales se ha dejado sentir, especialmente, en los campos de la salud, la evaluación y la educación (Bergman, 2011). La tendencia parece irreversible, hasta el punto de que son abundantes los autores

\section{Introduction}

The use of mixed research methods is setting itself as a new methodological movement, trying to overcome the old dualism established around quantitative versus qualitative (López-Fernández \& Molina-Azorín, 2011). According to Povee \& Roberts (2015), there are three reasons that explain the importance this research' perspective is acquiring in recent years: firstly, the increment permeability of the scientific communities in their ways of knowing and acting, opening itself to a more fluid paradigm and to an inclusive dialogue. Secondly, the continuous increment of the publication -since the gos - of works providing to this field with its own language, boosting the researches interested in the methodological plurality training's renewal. Finally, the significant increase in the edition of scientific journals articles using mixed methodologies.

It has a permanent expansion and popularity in the Social Sciences, especially in the fields of health, evaluation, and education (Bergman, 2011). The trend seems irreversible, to the point that there are several authors considering it as a paradigm with its own entity, even exploring the existence of different models in the bosom of the mixed methods (Harrits, 2011). In any case, its sui-

[ 140 ] JOSÉ ANTONIO CARIDE GÓMEZ Y RAÚL FRAGUELA-VALE

SIPS - PEDAGOGIA SOCIAL. REVISTA INTERUNIVERSITARIA [1139-1723 (2015) 26, 139-172] TERCERA ÉPOCA 
que llegan a considerarlo como un paradigma con entidad propia, explorando incluso la existencia de diferentes modelos en el seno de los métodos mixtos (Harrits, 2011). En todo caso, suele ponerse de manifiesto su idoneidad frente a otras opciones metodológicas más restrictivas o excluyentes, que para Teddlie \& Tashakkori $(2003,2009)$ permite valorar sus prácticas como más adecuadas que las aproximaciones monométodo: de un lado, porque permiten resolver preguntas de investigación que otros métodos no pueden; de otro, porque dan la posibilidad de hacer mejores inferencias; en tercer lugar, porque nos sitúan ante la oportunidad de presentar una gran diversidad de perspectivas, a menudo divergentes.

Sin embargo, emplear métodos mixtos de investigación no es fácil. Además de una visión epistemológica y metodológica poco convencional, requiere una mayor inversión en recursos, procedimientos, esfuerzos y dedicación en tiempo; al menos, si se compara con los enfoques de investigación que recurren a diseños menos complejos, que optan por un solo método. Además, los investigadores necesitan dotarse de un amplio conjunto de habilidades y competencias, con las que partiendo de una buena comprensión de la naturaleza y alcance de las metodologías cuantitativa y cualitativa, también puedan realizar su integración respondiendo de forma efectiva a los planteamientos y las preguntas de la investigación (Molina-Azorín, 2011). Tampoco es menor la dificultad -con frecuencia convertida en un verdadero desafío- que supone publicar estudios que utilizan métodos mixtos, ya que algunas revistas acostumbran a centrar su transferencia de conocimiento en los modelos cuantitativos o cualitativos. La necesidad de acomodar los textos a pocas páginas también suele limitar las opciones de editar los trabajos realizados con métodos mixtos.

El rápido crecimiento de esta perspectiva ha provocado un desarrollo dispar entre los supuestos teórico-conceptuales en los que se fundamenta y sus prácticas investigadoras. De hecho, la cuestión de cómo las diferentes metodologías y la aplicación de sus métodos deben interaccionar dentro de los diseños integrados, está lejos de resolverse. La articulación no se ha logrado como se esperaba y tardará tiempo en fraguarse desde el punto de vista metodológico, ya que se tability tends to become evident against other more restrictive or exclusionary methodological options, that allows to assess how appropriate that mono-methodological approaches practices are according to Teddlie \& Tashakkori (2003, 2009): on one hand, because it allows to answer research questions that other methods cannot; on the other hand, because they enable the creation of better inferences; thirdly, because it offers us a huge opportunity to present a variety of perspectives, often divergent.

However, using mixed methods research is not easy. In addition to an unconventional epistemological and methodological view, it requires greater investment in resources, procedures, efforts and time dedication; at least if compared with research approaches based on less complex designs, using a single method. In addition, researchers need to equip itself with a broad set of skills and competencies, which who (according to Molina-Azorín, 2011) are on the basis of a good understanding of qualitative and quantitative methodologies the nature and scope, and can also be integrative with and effective response to research questions and approaches. The difficulty -often turned into a real challenge- when publishing studies done with mixed methods, given that some journals tend to focus their knowledge transfer on the quantitative or qualitative models, is not less. The need to accommodate the texts to few pages also tends to limit the options when editing the mixed methods based papers.

The rapid growth of this perspective has led to an uneven development between their basic theoretical-conceptual assumptions and its research practices. In fact, the question of how the different methodologies and its methods' implementation must interact within the integrated designs is far from being solved. The enunciation has not been achieved as expected and it will take time to forge it from the methodological point of view, since it is still in its early theory and study stages (Greene, 2007). On the other hand, there are many projects - also publications- presented as examples of mixed methodologies that neither by the deficiencies or weaknesses that they reveal, nor by their ways of proceeding, deserve to be judged alike. 
encuentra todavía en sus primeras fases de teorización y estudio (Greene, 2007). Por otro lado, son muchos los proyectos -también las publicaciones- que se presentan como ejemplos de metodologías mixtas sin que ni por las carencias o debilidades que revelan, ni por sus formas de proceder, merezcan juzgarse como tales.

En esta línea, Bazeley \& Kemp (2012), a través de metáforas, intentan clarificar los distintos grados de integración que pueden deparar en el ámbito de los métodos mixtos. Describen un continuo que va desde las más elementales estrategias de combinación, juntando distintas metodologías pero -no necesariamente- adoptando una determinada secuencia o cambiando su estructura, hasta las estrategias generativas más sofisticadas, en las que dos o más componentes de un estudio interaccionan mutuamente, influyendo los resultados de uno en el diseño del otro, con la intención de ir más allá en la respuesta a las preguntas de investigación e, incluso, abrir nuevas vías de trabajo. Los autores advierten que utilizar distintas fuentes de datos o redactar las conclusiones de un estudio en base a distintas perspectivas no implica que ya se estén utilizando métodos mixtos; en su opinión deben respetarse una serie de principios para que tal integración metodológica llegue a darse (Bazeley \& Kemp, 2012):

- La existencia de distintas maneras de integrar los datos.

- La posibilidad de iniciar la integración en cualquier momento del estudio.

- Que la integración ocurra antes de redactar las conclusiones y esencialmente durante el análisis de resultados; por lo general, cuanto antes, mejor.

- El nivel de integración debe ajustarse a los objetivos del estudio.

- La forma en la que interaccionan los distintos elementos debe indicarse claramente en el informe de investigación.

- El producto o los resultados de la integración no podrían conseguirse sin ella.

- La redacción del informe de investigación debe organizarse en torno a los temas centrales del trabajo (sus preguntas de investigación, los objetivos, etc.) y no a los métodos de investigación empleados.
In this line, Bazeley \& Kemp (2012), through metaphors, tried to clarify the different degrees of integration on the field of mixed methods. They describe a continuum that goes from the most elementary strategies of combination, gathering different methodologies but - not necessarily adopting a particular sequence or changing its structure, up to more sophisticated-generative strategies, in which two or more components of a study interact, influencing the results of one on the design of the other, intending to go further in response to the research questions and even opening new path of work. The authors warned us that using different sources of data or write the conclusions of a study based on different perspectives does not imply that they are already using mixed methods; in their opinion a number of principles must be observed in order that such methodological integration occur (Bazeley \& Kemp, 2012):

- The existence of different ways to integrate the data.

- The possibility of starting the integration at any time during the study.

- Integration occurs before writing the conclusions and essentially during the results analysis; generally the sooner the better.

- The level of integration must conform to the research objectives.

- The way in which the various elements interact should be clearly indicated in the research report.

- The product or the results of the integration could not be reached without it.

- Research report writing should be organised around the central work issues (their research questions, objectives, etc.) and not on the research methods used.

- The report should not be drafted as a set of separate components; although the paper publication's rules hinder this task, search strategies for keeping the global overview should be applied.

Given those as are some of the "rules" of the mixed methodologies proposal's game, everything shows that it no can evade the perceptions and social representations made about them by the

[ 142 ] JOSÉ ANTONIO CARIDE GÓMEZ Y RAÚL FRAGUELA-VALE 
- El informe tampoco deberá redactarse como un conjunto de componentes separados; aunque las normas de publicación de los trabajos dificulten esta labor, han de buscarse estrategias para que no se pierda la visión de conjunto.

Si estas son algunas de las "reglas" del juego en el que inscriben sus propuestas las metodologías mixtas, todo indica que no podrán sustraerse de las percepciones y representaciones sociales que sobre ellas hacen las comunidades académicas y científicas más resistentes a innovar sus prácticas.

\section{Un giro metodológico, alentado por el diálogo paradigmático}

La investigación en Ciencias Sociales y, más en concreto, de aquellas que hacen de la Educación su tema-problema y objeto de indagación, concluyó el siglo $X X$ con unas magníficas perspectivas. De un lado, no sin dificultades, todo indica que se ha debilitando el poder de las voces que cuestionan su identidad y entidad como un ámbito del conocimiento científico -complejo, plural, emergente, etc.- susceptible de un quehacer intelectual riguroso, epistemológica y metodológicamente consistente; de otro, tras la secular dominación de la racionalidad positivista -construida poniendo énfasis en la legitimidad metódica de los procedimientos matemáticos, físicos y experimentales- la Humanidad asume la necesidad de otras búsquedas, no sólo de las certezas y verdades absolutas (más pretendidas que reales) sino de las evidencias, razones, explicaciones o comprensiones que están detrás de los hechos, restaurando -como diría Toulmin (2003: 33)- "el equilibrio adecuado entre la teoría y la práctica, la lógica y la retórica, la racionalidad y la racionabilidad".

Además, sin que sea una cuestión menor, seguimos inmersos en una incesante revisión de los supuestos que subyacen a los modos de mirar la realidad (en el sentido etimológico con el que comenzó nombrándose a la theoria, como la acción de contemplarla con criterios juiciosos y serenos), de aprehenderla, analizarla e interpretarla. Por lo tanto, no sólo como una forma de asociar la lógica del método a lo que hay o a lo que se observa en el devenir de las circunstancias, sino también como la oportunidad que nos dan los saberes para poder toughest academic and scientific communities to innovate their practices.

\section{A methodological shift, encouraged by the paradigmatic dialogue}

Research in Social Sciences and, in particular, those that make education its issue-problem and object of inquiry, ended the 2oth century with magnificent prospects. On one side, (and not without difficulties) everything indicates that is has weakened the power of the voices questioning their identity and entity as an area of scientific knowledge - complex, plural, emergent, etc. - susceptible of a rigorous, epistemological and methodologically consistent intellectual work; on the other side, after the secular domination of the positivist rationality - built with emphasis on methodical legitimacy of mathematical, physical and experimental procedures - the humankind assumes the need for other searches not only of certainties and absolute truths (more alleged than real) but of evidences, reasons, explanations or comprehensions behind the facts, restoring - as Toulmin said (2003: 33) - "the right balance between theory and practice, logic and rhetoric, rationality and reasonableness".

Moreover, without being a minor issue, we are still involved in a constant review of the assumptions underlying the ways of looking at reality (in the etymological sense with which the theory was first called, as the action to contemplate it with wise and serene criteria), of apprehend, analyse and interpret it. Therefore, not only as a way to associate the method logic to what there is or what is observed in the course of the circumstances, but also as an opportunity that knowledge gives us to transform and intervene on them: the 
transformarlas e intervenir en ellas: la voluntad, no siempre explícita, de dar coherencia a los acontecimientos cotidianos o extraordinarios, posicionándose éticamente ante lo que promueven o inhiben. En síntesis, de adoptar una postura crítica ante la realidad y su transformación, alejada de concepciones fragmentarias del mundo, de la Humanidad y del conocimiento.

No se trata, convenimos con Popkewitz (1988), de minusvalorar la importancia de una atención cuidadosa al mundo empírico o de las formalidades exigibles a todo quehacer científico bien conducido u orientado. Tampoco de obviar lo que toda ciencia en sus propósitos y en los resultados que deparaoculta como discurso político e interés práctico, con demasiada frecuencia guiados por afanes económicos, ideológicos, religiosos o éticos poco o nada estimables. Muy al contrario, sin que pasemos por alto sus reglas de juego (Kuhn, 1962), la intención no es otra que ampliar el alcance de las palabras y las cosas en la mejora de la vida de las personas, sea cual sea el campo disciplinar en el que se concrete. Una disposición cognitiva que trasciende una visión morfológica de la ciencia para reivindicar sus connotaciones cívicas y morales. Sin duda, lo son las que desde hace décadas vienen alentando a la Pedagogía Social a la hora de optar por unos u otros modos de enfocar los problemas y buscar las respuestas.

El método como métodos, afirmando la idoneidad de su pluralismo en el continuo diálogo que media entre el conocer y el hacer, el diseño y sus procesos, el pensamiento y la acción. Armonizar sus fortalezas y debilidades requiere convicción, determinación y prudencia. Lo declaraba Bericat (1998: 56) al defender los diseños multimétodo poco tiempo atrás, impregnando el debate suscitado acerca de los pros y contras de la investigación cuantitativa versus cualitativa, más allá de los convencionalismos heredados: "una actitud de prudencia metodológica a la hora de integrar métodos, sin la cual no tendría sentido hablar de verdaderos diseños multimétodo, sino más bien de meras yuxtaposiciones desordenadas o absurdos agrupamientos técnicos. Complementariamente al principio de prudencia, sostenemos con idéntica convicción el principio de utilidad, dado que muchos resultados falaces obtenidos en las investigaciones sociales hubieran podido corregirse mediante una oportuna y will, not always explicit, to give coherence to everyday or extraordinary events positioning itself ethically against what they promote or inhibit. In short, it is the adoption of a critical attitude towards reality and its transformation away from fragmentary conceptions of the world, Humanity and knowledge.

It is not, as Popkewitz (1988) said, to underestimate the importance of a careful empirical world attention or the required formalities to all well led or driven scientific work. Either ignoring what all science - in their purposes and the results that offers - hides as political discourse and practical interest, very often guided by economic, ideological, religious or ethical means with little or nor valuable at all. On the contrary, without ignoring their game rules (Kuhn, 1962), the intention is to expand the words scope and things for the humankind live improvement, whatever discipline field in which it appears. It can be seen as a cognitive willingness that transcends a morphological view of science claiming for their civic and moral connotations. Undoubtedly, for decades Social Pedagogy was encouraged when opting for one or the other ways of focusing problems and seeking answers.

These method claims for the suitability of its pluralism in the continuous dialogue between knowing and doing, design and processes, thought and action. Harmonize their strengths and weaknesses require conviction, determination and prudence. Bericat stated (1998:56) that defending multi-method designs not so long ago, permeated the raised debate about the pros and cons of quantitative versus qualitative research, beyond the inherited conventions: "an attitude of methodological prudence when it comes to integrate methods, without which it would not make sense to speak of real multi-method designs, but rather merely cluttered juxtapositions or absurd technical groupings. In addition to the principle of prudence, we hold with identical conviction the principle of utility, since many spurious obtained results of social research had failed to correct through a timely and coherent integration". Or, in other terms, making the paradigmatic dialogue a con-substantial dimension method, the meanings that emerge within their

[ 144 ] JOSÉ ANTONIO CARIDE GÓMEZ Y RAÚL FRAGUELA-VALE 
coherente integración". O, expresado en otros términos, haciendo del diálogo paradigmático una dimensión consustancial al método, a los significados que emergen con sus prácticas y a las transformaciones que se producen en su interior.

Los supuestos epistémicos a los que se remiten sus puntos de inflexión, entre el disenso y el consenso de quienes los protagonizan, han llegado a identificarlo con el modelo dialéctico o dialógico, en lo que comporta de revisión general de las metodologías y sus enfoques, de las estrategias y las técnicas, de los recursos e instrumentos al uso (Martínez, 2006). Mientras la racionalidad instrumental emplea el lenguaje como un medio con el que conseguir unos determinados fines, la racionalidad dialógica utiliza el lenguaje como un medio puesto al servicio de la comunicación y el entendimiento (Habermas, 1987).

El fundamentalismo que dirigió la filosofía de la ciencia y la lógica del método durante siglos ya no está justificado, sin que por ello la concepción evolutiva del conocimiento nos aboque necesariamente al relativismo o a las trampas de cualquier dualismo (cuantitativo-cualitativo, sujeto-objeto, inductivo-deductivo, nomotético-idiográfico, etc.). Más que elecciones apriorísticas y unidireccionales, los métodos devienen en alternativas deliberadas, a las que estimula la comunicación y la reflexión colectiva, la interdisciplinariedad y sus complejidades intrínsecas, evocando lo diverso y lo híbrido, lo que se enfrenta o converge; los denominados "métodos mixtos" son uno de sus exponentes. La importancia de las alianzas metodológicas, que Gutiérrez (2008: 75) ejemplifica en la investigación socioambiental, se suma a los cambios que traen consigo sucesos recientes, que "nos han obligado a reformatear la memoria colectiva y sus provisionales certidumbres, a mirar con otros ojos el entorno que nos rodea, a modificar nuestros esquemas de pensamiento, a revisar nuestras formas de explicar y las maneras de entender lo que ocurre a nuestro alrededor para poder actuar con conocimiento de causa".

No aludimos al experimentalismo de una metodología mixta que, como advierten Denzin \& Lincoln (2012: 60), "excluye a los participantes del diálogo y la colaboración activa en los procesos de investigación", debilitando la dimensión democrática y dialógica que le es inherente, presu- practices and the transformations that occur in its interior.

The alleged epistemic who refer their tipping points, between dissent and the consensus of those who lead them, have come to identify it with the dialectical model, an overall review on methodologies and their approaches, strategies and techniques, resources and tools available (Martinez, 2006). While the instrumental rationality uses the language to achieve a certain end, dialogical rationality uses language for communication and understanding (Habermas, 1987).

The fundamentalism that led the philosophy of science and logic of the method for centuries is not justified any more, it not lead us to the evolutionary conception of knowledge us respecting relativism or the pitfalls of any dualism (quantitative - qualitative, subject-object, inductive-deductive, nomothetic-ideographic, etc.). More than forehand and unidirectional chooses, the methods become deliberate alternatives, stimulating communication and collective reflection, interdisciplinary nature and its intrinsic complexities, evoking the diversity and the hybrid, which faces or converge; the so-called "mixed methods" are one of its exponents. The importance of methodological partnerships, as Gutiérrez (2008: 75) shows in the socio-environmental research, are added to those of recent events that "we have forced to reformat from collective memory and their provisional certainties, to look with different eyes our environment, to change our thought patterns, to revise our ways of explaining and ways to understand what is happening around us so we can act with knowledge of the cause".

We neither allude to the experimentalism of a mixed methodology that, as Denzin \& Lincoln (2012: 60) stated, "exclude the dialogue participants and active collaboration in research processes", weakening the inherent democratic and dialogical dimension, boasting a methodological hierarchy in which quantitative methods are superior, relegating the qualitative ones to an auxiliary role. Nor to a type of research that eagerness give voice to the people, emphasizing the weight of subjectivity, the emotions or the story, overlooked the scientific anchor that underlies its multiple forms of meeting, interpreting and 
miendo de una jerarquía metodológica en la cuál los métodos cuantitativos son superiores, relegando los cualitativos a un rol auxiliar. Tampoco a un tipo de investigación que en sus ansias por dar voz a la gente, poniendo de relieve el peso de la subjetividad, de las emociones o del relato, pase por alto el anclaje científico que subyace a sus múltiples formas de conocer, interpretar y transformar la realidad, tanto como sea deseable y viable. La integración, cuando se invoca lo mixto, no traza fronteras acerca de lo que está dentro o fuera de sus territorios conceptuales, teóricos, metodológicos, empíricos, procedimentales... sino que las abre a su convivencia respetuosa y tolerante. Las formas de hacerlo y no sólo sus para qué o por qué son determinantes, máxime cuando "las técnicas no son ajenas a la naturaleza de la investigación, pues dependen de ella, lo mismo que la calidad de la investigación está sujeta a las técnicas utilizadas (...) porque las técnicas satisfagan las necesidades que el tema de estudio plantea, y por su pertinencia para cubrir los objetivos y/o hipótesis formuladas, al igual que el propósito de la investigación debe determinar las técnicas que se van a utilizar. Lo que da garantía a la información es el procedimiento y rigurosidad con que el equipo de investigación aborda el estudio" (Gómez, Latorre, Sánchez \& Flecha, 2006: 78-79).

\section{Ampliando las expectativas: validación, generación de conocimiento y cambio social}

La historia de la integración metodológica tiene sus orígenes en la triangulación. Como se sabe, una de las primeras y legítimas finalidades ligadas a los métodos mixtos es el aumento de la validez de y en los estudios. La triangulación, que inicialmente se utilizó para referirse a la complementariedad o confluencia de varios métodos dentro de un mismo paradigma (cuali-cuali o cuanti-cuanti), pronto se incorporó al ámbito científico como la combinación de métodos de ambos paradigmas, siendo una de las puntas de lanza de la integración metodológica durante años.

Desde su perspectiva más restringida (tradicional), la triangulación se conceptualizó como una integración convergente de los métodos cuantitativo y cualitativo al objeto de satisfacer un mismo pro- transforming reality, as much as it is desirable and feasible. Integration, when evoking a mixed concept, do not draw boundaries on what is within or outside their conceptual, theoretical, methodological, empirical, procedural territories; it opens them towards a respectful and tolerant coexistence. The ways of doing it and not only their "why?" or "for what?" are decisive, especially when "techniques are not foreign to the research's nature, because they depend on it, as well as the quality of research depend on the performed techniques... because the techniques meet the needs posed by the topic of study, and by their relevance to meet the objectives and/or formulated hypotheses, as in the purpose of the research that must determine the techniques that will be used. What guarantee the information is the procedure and thoroughness with which the research team deals with the study"(Gómez, Latorre, Sánchez \& Flecha, 2006: 78-79).

\section{Expanding expectations: validation, generation of knowledge and social change}

The history of the methodological integration has its origins in the triangulation. As it is known, one of the first and legitimate purposes related to mixed methods is the increase of the validity of and in the studies. Initial triangulation used to refer to the complementarity or confluence of several methods within the same paradigm (qualitative-qualitative or quantitative-quantitative), soon joined the scientific sphere as the combination of methods of both paradigms, being one of the milestones of the methodological integration for years.

From their more restricted perspective (traditional), triangulation was conceptualized as a convergent integration of quantitative and qualitative methods in order to satisfy a given purpose of re-

[ 146 ] JOSÉ ANTONIO CARIDE GÓMEZ Y RAÚL FRAGUELA-VALE 
pósito de investigación. En este sentido aspiraba a lograr la corroboración, correspondencia o concurrencia de resultados provenientes de distintos métodos, perspectivas, agentes o datos con la finalidad de acrecentar la validez interna y externa de los mismos. Así, en la estrategia de triangulación, cuanto más diferentes sean los métodos que concuerden en los resultados, mayor será la evidencia de su veracidad; y viceversa.

Sin embargo, las críticas a las que se vio sometida esta concepción en los años 80 y en los primeros 90 del pasado siglo (Flick, 1992), indujo una reformulación de sus planteamientos, reconociendo no solo su potencial como un recurso para la validación, sino también para la generación de nuevos conocimientos. Desde un enfoque constructivista, a pesar de que al triangular los resultados de distintos colectivos (por ejemplo, alumnos y profesores, jóvenes y adultos) éstos no converjan o corroboren una determinada afirmación, la triangulación permitirá incidir en la calidad de la investigación, o -cuando menos- en la pluralidad de la información que proporcionan. Siendo así, el contraste entre lo que aportan diferentes poblaciones, sujetos o informantes clave, podrá derivar en mayores y mejores oportunidades para el conocimiento (Flick, 2008; Flick, Garms-Homolová, Herrmann, Kuck, \& Röhnsch, 2012).

En este punto arranca una discusión terminológica y conceptual que se prolonga hasta nuestros días, al tratar de diferenciar la triangulación de los métodos mixtos: "la investigación con métodos mixtos implica triangulación. ¿̇ no? Depende de cómo se conciba cada concepto" (Howe, 2012: 89). Se pueden identificar tres posiciones: la primera considera los métodos mixtos y la triangulación como sinónimos, la segunda concibe la triangulación como una parte de los métodos mixtos, mientras que la tercera incluye los métodos mixtos en la triangulación (Bergman, 2011). Cabe advertir que a medida que la generación de conocimiento se ha ido asentando como una de las finalidades de la integración metodológica, la triangulación ha dejado de abarcar conceptualmente a los métodos mixtos, que aumentan su alcance y acabarán tratándola como una de sus tipologías. De esta forma, ha pasado a aceptarse que la triangulación es un tipo de investigación en métodos mixtos que apunta a la convergencia. search. In this sense it aimed to obtain corroboration, correspondence or concurrence of results from different methods, prospects, agents or data in order to enhance their internal and external validity. Thus, in the triangulation strategy, the more different the methods agreeing with the results are, the greater evidence of its truth; and vice versa.

However, criticism to this conception in the 80 s and early 90 s (Flick, 1992) induced to a reformulation of their approaches, recognizing not only its potential as a validation source, but also for the generation of new knowledge. From a constructivist approach, despite the fact that when triangulating the results of different groups (i.e, students and teachers, young people and adults) they do not converge or corroborate a particular statement, triangulation will allow influencing the quality of the research, or - at least- the plurality of the information provided. Thus, the contrast between what different populations provide, subjects or key informants, can lead to bigger and better opportunities for knowledge (Flick, 2008;) Flick, Garms-Homolová, Herrmann, Kuck, \& Röhnsch, 2012).

At this point starts the terminological and conceptual discussion that lasts to the present day, trying to differentiate the triangulation of the mixed methods: "mixed methods research involves triangulation. Or not? It depends on how each concept is conceived"(Howe, 2012: 89). Three positions can be identified: the first considers mixed methods and triangulation as synonyms; the second conceives triangulation as a part of mixed methods; while the third includes mixed methods in triangulation (Bergman, 2011). It should be noted that as long as the generation of knowledge was set as one of the goals for methodological integration, triangulation no longer covered mixed methods that enhance their reach and eventually dealing with it a typology. In this way, triangulation has been recognized as a type of research in mixed methods aiming at convergence.

In the approach by Greene \& Caracelli (2003) the different forms of organizing methods of study, based on the purpose of generating new knowledge, triangulation appears as one of the five ways of combining methods: 
En la aproximación que hacen Greene \& Caracelli (2003) a las distintas formas de organizar los métodos de un estudio, tomando como referencia la finalidad de generar nuevo conocimiento, la triangulación aparece como una de las cinco formas de combinar métodos:

1. Triangulación o búsqueda de convergencia de resultados: usando diferentes métodos para investigar un mismo fenómeno, si los resultados se confirman mutuamente su validez será mayor.

2. Complementariedad o estudio del solapamiento de distintos aspectos de una realidad: buscando elaborar, ilustrar, destacar o clarificar los resultados de un método a través de los resultados de otro.

3. Iniciación o descubrimiento de contradicciones: estas paradojas en muchas ocasiones provocan el replanteamiento de las preguntas que están en el origen de la investigación.

4. Desarrollo secuencial de los instrumentos entre sí: utilizando los resultados de un método para desarrollar un segundo método, intentando aumentar la profundidad y el alcance de la investigación.

5. Expansión o extensión del proyecto a medida que avanza en su desarrollo.

A estas combinaciones se asocian diferentes diseños, cada uno de ellos persiguiendo objetivos o fines específicos. En la tipología que formulan Teddlie \& Tashakkori (2003) se contemplan cuatro opciones: diseños de triangulación, de incrustación de dominancia, de exploración secuencial y de explicación secuencial. Más adelante nos basaremos en esta clasificación para mostrar la integración metodológica de la que se viene haciendo uso en el proyecto RESORTES.

Hay, no obstante, otra cuestión en la que es preciso detenerse cuando se alude a las finalidades de los métodos mixtos. La sugieren Johnson, Onwuegbuzie, \& Turner (2007: 123) cuando aluden a la metodología mixta como "un tipo de investigación en la que el investigador o equipo de investigadores combinan elementos de la investigación cualitativa y cuantitativa (por ejemplo, el uso de puntos de vista, recogida de datos, análisis, técnicas inferenciales) con el objetivo general de ampliar y profun-
1. Triangulation or search for results' convergence: using different methods to investigate the same phenomenon, if the results are mutually confirmed their validity will be higher.

2. Complementarity or study of the different aspect of reality overlapping: seeking to elaborate, illustrate, highlight, or clarify the results of a method through the results of another.

3. Initiation or discovery of contradictions: these paradoxes often drive to rethink the questions at the origin of the research.

4. Sequential development of instruments among themselves: using the results of a method for developing a second one, trying to increase the depth and the scope of the investigation.

5. Expansion or extension of the project as long as it is developed.

These combinations are associated to different designs, each of them pursuing specific goals or purposes. The typology formulated by Teddlie \& Tashakkori (2003) includes four options: triangulation designs, dominant embbeded designs, exploratory sequential designs and explanatory sequential designs. Later we will rely on this classification to show the methodological integration in which the RESORTES project is applied.

There is, however, another issue where we should recall when referring to the purposes of mixed methods. Johnson, Onwubgeuzie, \& Turner suggested it (2007: 123) when they refer to the mixed methodology as "a type of research in which the researcher or team of researchers combined elements of qualitative and quantitative research (i.e., the use of points of view, data gathering, analysis and inferential techniques) with the overall goal of broadening and deepening in the understanding of a phenomenon and the results confirmation". Your opinion seems to clarify the ultimate aim of mixed methods, coinciding with what is expressed by other authors: validate and expand knowledge.

However, recently some voices claiming for this type of research in a higher level of demand, which shares the Social pedagogy socio-critical and emancipatory, had appeared. Those are the ar-

[ 148 ] JOSÉ ANTONIO CARIDE GÓMEZ Y RAÚL FRAGUELA-VALE 
dizar en la comprensión de un fenómeno y en la confirmación de los resultados obtenidos". Su opinión parece aclarar la finalidad última de los métodos mixtos, coincidiendo con lo expresado por otros autores: validar y expandir los conocimientos.

Sin embargo, recientemente han aparecido voces que reclaman para este tipo de investigación un mayor nivel de exigencia, que comparte la Pedagogía Social emancipatoria y socio-crítica. Son los argumentos de quienes defienden que el trabajo de los investigadores -y, por extensión de los educadoresdebe contribuir al cambio social, atribuyéndole al empleo de metodologías mixtas la capacidad de ponerse al servicio de dicho cambio. Sin aludir a ellas literalmente, la metodología comunicativa crítica (Gómez, Latorre, Sánchez \& Flecha, 2006) se compromete con tal posibilidad, al considerar que la cuestión no reside tanto en utilizar uno u otro tipo de técnicas de recogida de la información como en la participación de los sujetos -personas o colectivos- en las tareas que van desde el diseño hasta el final, en sus conclusiones y recomendaciones. La meta principal es la comprensión explicativa y la transformación de la realidad social.

Lo apunta Mertens (2007) al reivindicar la necesidad de incorporar a los miembros de las comunidades estudiadas a las primeras fases de los procesos de investigación, especialmente a la discusión de los que serán temas centrales de la indagación. En lo que denomina como paradigma transformador, se dan cita argumentaciones en los planos ontológico, epistemológico, axiológico y metodológico. Sobre esta última dimensión indica que: "un investigador puede elegir metodologías cuantitativas, cualitativas o mixtas, pero debería haber una relación interactiva entre el investigador y los participantes en la definición del problema, los métodos se deberían ajustar a la complejidad cultural, las relaciones de poder explícitamente abordadas y las cuestiones relativas a la discriminación y la opresión deberían reconocerse" (Mertens, 2007: 216).

La autora destaca el potencial de los métodos mixtos para ayudar a los colectivos más desfavorecidos a generar cambios sociales positivos en sus entornos. Recuerda que los colectivos que viven situaciones de desigualdad por motivos como la raza/etnia, género, idioma, discapacidad, religión, nivel económico, inmigración, etc., cada vez muestran guments of those who defend the researchers' work - and, by extension educators' - that should contribute to social change, attributing the used of mixed methodologies the ability to boost such a change. Without literally alluding to them, the critique communicative methodology (Gómez, Latorre, Sánchez \& Flecha, 2006) is committed to such possibility, considering that the question is not about using one or other data gathering technique but about the subjects participation - people or groups- in tasks ranging from design to the end in its conclusions and recommendations. The main goal is the explanatory understanding and transformation of social reality.

Mertens (2007) stated that by claiming the need to incorporate members of the studied communities to the early stages of the research processes, especially in the discussion, would be the central issues of inquiry. In what is called transforming paradigm, arguments at the ontological, epistemological, axiological and methodological levels appear. On this last dimension indicates that: "A researcher can choose quantitative or qualitative or mixed methods, but there should be an interactive link between the researcher and the participants in the definition of the problem, methods should be adjusted to accommodate cultural complexity, power issues should be explicitly addressed, and issues of discrimination and oppression should be recognized" (Mertens, 2007: 216).

The author highlights the potential of mixed methods to help the most disadvantaged to generate positive social changes in their environments. He reminds us that the collective living inequality situations such as race/ethnicity, gender, language, disability, religion, economic level, immigration, etc., are increasingly showing a greater and, even legitimate, refusal to researchers who just gather data and do not help to change their realities (Mertens, 2011, 2013). It should not be overlooked that mixed methodology can be used to identify, support, and include the collective voices in researches, some of which (the less powerful) can be silenced when using a unique research paradigm; also to reveal different versions of reality, including their relations with the power and privileged groups, identifying in each context 
un mayor y, podríamos decir que legítimo, rechazo a aquellos investigadores que se limitan a tomar datos y no ayudan a cambiar sus realidades (Mertens, 2011, 2013). No debe pasarse por alto que la metodología mixta puede ser utilizada para identificar, apoyar e incluir en las investigaciones las voces de distintos colectivos, algunos de los cuales (los menos poderosos) pueden quedar silenciados cuando se emplea un único paradigma de investigación; también para revelar diferentes versiones de la realidad, incluyendo sus relaciones con el poder y los colectivos privilegiados, identificando en cada contexto los aspectos que generen o favorezcan cambios sociales positivos.

Otros autores, como Bergman (2011), aun reconociendo el potencial de los métodos mixtos para favorecer el cambio social, considera que esta finalidad debe ser tomada con cautela. Argumenta que la investigación participativa o transformadora puede llevarse a cabo con cualquier método de investigación. Serán los objetivos que se plantee el investigador y no las peculiaridades de la recogida o del análisis de datos los que determinarán que una investigación pueda ayudar a transformar la realidad, afrontando las desigualdades o los desequilibrios existentes en una determinada comunidad.

Nos situamos con ello ante una de las cuestiones más problematizadoras de las metodologías mixtas, que atraviesan todas las circunstancias que la afectan, desde la revisión de la literatura hasta la teorización de su diseño, pasando por los procedimientos, las técnicas o el análisis de la información proveniente del trabajo empírico; también, sin duda, por los modos de comunicar y transferir el conocimiento, de publicarlo y compartirlo con quienes lo han generado.

\section{Investigando los tiempos educativos y sociales en red: OcioGune y el proyecto RESORTES}

Los métodos mixtos demandan el trabajo conjunto de equipos o grupos de investigadores, que desde distintos ámbitos del conocimiento deciden vincularse para formular preguntas de investigación complejas que salen al encuentro de respuestas con las que se pretende mantener niveles equiparables de complejidad. A pesar del interés ma- the aspects that generate or facilitate positive social changes.

Other authors, such as Bergman (2011), even recognizing the potential of mixed methods to promote social change, consider that this objective should be taken with caution. He argues that participatory or transformative research can be performed with any method of research. They will be the objectives of the researcher and not the peculiarities of data gathering or analysis which will determine if a research may help to transform reality, tackling inequalities or existing imbalances in a particular community.

We are facing one of the more difficult questions mixed methodologies - spanning all circumstances that affect it-, since the review of the literature to the theorisation of its designs, procedures, techniques and analysis of information from empirical work; also, without a doubt, the ways of communicating, transferring, publishing and sharing knowledge with those who have created it.

\section{Investigating the social and educational times at a network: OcioGune and the RESORTES project}

Mixed methods require the joint work of teams or groups of researchers from different fields, who decide to work together to create complex research's questions trying to give answers to maintain comparable levels of complexity. Despite the interest expressed by various entities and organizations (Foundations for Science and Techno- 
nifestado por distintas entidades y organismos (Fundaciones para la Ciencia y la Tecnología, sociedades científicas, Universidades, etc.) por impulsar iniciativas que se apoyen en redes $y$ agrupaciones científicas interdisciplinares, con el impulso de las Administraciones Públicas a través de convocatorias orientadas a financiar su estructuración competitiva, se conoce poco sobre la gestión y las dinámicas internas de estos equipos. Una circunstancia, en parte, explicada por la necesidad de situarse mucho más en los resultados del trabajo realizado -en términos de producción científica y de transferencia de conocimiento- que en los modos de hacerlo, que no reside sólo en las metodologías que utilizan, sino en todos los procesos que las acompañan, desde la constitución y dinamización del equipo o de los equipos en red hasta las decisiones y actuaciones que comportan. Cómo trabajan los equipos y cómo trenzan sus redes colaborativas, haciendo uso de métodos mixtos y propiciando tareas colaborativas o cooperativas (en escenarios competitivos), todavía depara más interrogantes que respuestas.

No obstante, distintos autores han descrito los sistemas de trabajo en equipo con métodos mixtos. Es el caso de Shulha \& Wilson (2003), quienes identifican grupos distanciados, relacionados o integrados; de O'Cathain, Murphy \& Nicholl (2008) al distinguir entre equipos multidisciplinares, interdisciplinares e incluso disfuncionales, etc. Estos modelos aluden a distintas categorías o niveles de interacción, que transitan desde una colaboración débil hasta un trabajo fuertemente integrado, ya sea en función de la motivación e implicación de los miembros de los equipos para trabajar juntos, de su nivel de formación y de la experiencia que acumulan en métodos mixtos, de sus percepciones sobre el estatus de las metodologías cuantitativa y cualitativa, de la fluidez de la comunicación entre las partes, de la distancia geográfica entre los equipos, de la actitud de los investigadores principales hacia la metodología mixta, etc.

De su y nuestra experiencia cabe inferir que el trabajo colaborativo e integrado con métodos mixtos genera más expectativas que realidades, al menos en los cortos y medios plazos. Sus logros son más fáciles de anticipar que de conseguir, ya que aún cuando existan estímulos institucionales e in- logy, scientific societies, Universities, etc.) to promote initiatives that support networks and interdisciplinary scientific groups, with the impulse of Public Administrations through targeted calls to finance its competitive structure, little is known about the internal dynamics and management of these teams. A circumstance, in part, explained by the need to be much more focused on the results of the carried-out work - in terms of scientific production and knowledge transfer-to do so, which lies not only in the used methodologies, but in all processes that accompany them, since its constitution and boosting teams or networking for the decisions and actions involved. How teams work and how their collaborative networks are created, using mixed methods and promoting cooperatives or collaborative tasks (in competitive scenarios), still leaves more doubts than answers.

However, different authors have described team-working systems with mixed methods. It is the case of Shulha \& Wilson (2003), who identified apart, related or integrated groups; and for O'Cathain, Murphy \& Nicholl (2008) to distinguish between multidisciplinary, interdisciplinary, and even dysfunctional teams, etc. These models refer to different interaction categories or levels, transiting from a weak collaboration to a strongly integrated work, either depending on the motivation and involvement of members of the teams to work together, their level of training and experience that accumulate in mixed methods their perceptions about the status of quantitative and qualitative methodologies, the flow of communication between the parties, of the geographical distance between the teams, the attitude of the principal investigators to the joint methodology, etc.

From their and our experience, it should be inferred that the collaborative and integrated work with mixed methods generate more expectations than realities, at least in the short and medium terms. Their accomplishments are easier to anticipate than to achieve, since even though there are personal institutional incentives and even will - not to say interests - of researchers, there are barriers that complicate the realization of an effective and sufficiently coordinated work, especially when the aim is to develop mixed methods, 
cluso voluntad -por no decir intereses- personales por parte de los investigadores, existen barreras o adversidades que complican la realización de un trabajo efectivo y suficientemente coordinado, sobre todo cuando se pretenden desarrollar métodos mixtos, muy exigentes con el compromiso y la responsabilidad que adquieren los equipos que tejen la red, que en última instancia son las de los investigadores y las investigadoras que los componen.

En el campo de la Psicología, Povee y Roberts (2015) estudiaron las actitudes de estudiantes y académicos -profesores e investigadores- hacia la metodología y los métodos mixtos. Encontraron que algunos de los participantes eran escépticos respecto al rigor de esta metodología; la mayoría, sin embargo, se mostraban abiertos a los métodos mixtos, a pesar de lo cual reconocían insuficiente formación o experiencia para desarrollar investigaciones de estas características. Por su parte, Curry et al. (2012), desde las Ciencias de la Salud, describen los retos o limitaciones a superar por los equipos que desarrollan proyectos conjuntos con una metodología mixta: gestionar las diferencias entre los equipos cohesionando a sus miembros, desarrollar la confianza mutua, crear un grupo significativo, manejar conflictos y tensiones, y favorecer la aparición de roles de liderazgo efectivos dentro de los grupos. Hacen una propuesta de principios a seguir para responder a estos propósitos, basados en los resultados de su trabajo.

En este contexto, lleno de oportunidades, pero también de incertidumbres y desafíos, siete equipos de otras tantas Universidades españolas asumimos la participación en un proyecto conjunto, que acomodando sus propuestas a la modalidad de proyectos coordinados en el marco del Plan Nacional de I+D+i, pretende alcanzar un alto grado de convivencia grupal, tanto en su estructura como en su funcionamiento.

La interdisciplinariedad y la integración metodológica son dos de las características que guían el proyecto RESORTES, en gran medida posible gracias a la creación, en 2009, de la Red OcioGune (siendo "gune" un vocablo que, en euskera, tiene el significado de "espacio" o "lugar" de encuentro), estableciendo vínculos con los que dar continuidad a la convocatoria anual, a partir de 2006, del "Foro de Investigación, Pensamiento y Reflexión en torno al fe- very demanding with the commitment and responsibility acquired by teams on the network which eventually are those of the researchers.

In the field of Psychology, Povee y Roberts (2015), studied the attitudes of students and academics - professors and researchers - towards methodology and mixed methods. They found out that some participants were sceptical regarding this methodology's rigour; however most of them were receptive to mixed methods, despite of recognizing their insufficient training or experience to develop such research. For their part, Curry et al. 2012), in the Health Sciences, describe the challenges or limitations to overcome by the teams that develop joint projects with a mixed methodology: to manage the differences between the teams by bringing their members together, developing mutual trust, creating a significant group, managing conflicts and tensions, and favouring the emergence of effective leadership roles within groups. They make a proposal of principles to follow in order to serve these purposes, based on the results of their work.

In this full of opportunities but also uncertainties and challenges' context, seven teams of other Spanish Universities assume participation in a joint project, by integrating their proposals to the projects coordinated in the framework of the National Plan for R\&D; aiming to achieve a high degree of group living, both in its structure and in its operation.

Interdisciplinary and methodological integration are two of the features that guide the project RESORTES, which is mainly possible by the creation, in 2009, of the OcioGune Network ("gune" means "space" or "meeting place" in Basque), establishing links to give continuity to the annual call for proposals, from 2006 the "Forum of Research, Thinking and Reflection on the leisure phenomenon ", organised by the Leisure Studies Institute of the University of Deusto: an open space-time for scientific debate and the sharing on leisure in contemporary society, with the participation of researchers attached to Latin American and American Universities.

[ 152 ] JOSÉ ANTONIO CARIDE GÓMEZ Y RAÚL FRAGUELA-VALE 
nómeno del Ocio", convocado por el Instituto de Estudios de Ocio de la Universidad de Deusto: un espacio-tiempo abierto al debate científico y a la puesta en común sobre el ocio en las sociedades contemporáneas, con la participación de investigadoras e investigadores adscritos a distintas Universidades españolas, europeas, latinoamericanas y norteamericanas.

\subsection{La red OcioGune y sus equipos de investigación}

La red de equipos de investigación OcioGune, dirigida por el Dr. Manuel Cuenca, actualmente catedrático emérito de la Universidad de Deusto, reúne a siete equipos de investigación especializados en el estudio del ocio y temáticas afines, fomentando la investigación cooperativa en este ámbito del saber, del que el denominado Proyecto RESORTES constituye uno de sus principales exponentes (Caride, Fraguela \& Varela, 2014). El punto de confluencia de los grupos que la integran reside en la adhesión a los principios del ocio humanista y el reconocimiento de la contribución del ocio al desarrollo humano (personal y social). Cada equipo está especializado en distintas temáticas, abordadas desde enfoques y disciplinas diversas (Pedagogía, Sociología, Psicología, Geografía, Economía, Ciencias de la Actividad Física y del Deporte, etc.) que garantizan la complementariedad de sus temas y el carácter multi-inter-disciplinar con el que la red ha querido dotarse desde sus inicios. Los integrantes de la red, que han participado desde sus inicios en su constitución, en el diseño e implementación del Proyecto RESORTES son:

- El equipo de investigación en Pedagogía Social y Educación Ambiental (SEPA-interea), adscrito al Departamento de Teoría de la Educación, Historia de la Educación y Pedagogía Social de la Facultad de Ciencias de la Educación de la Universidad de Santiago de Compostela, reconocido como grupo de referencia competitiva en el sistema universitario gallego, del que es coordinador-IP el Dr. José Antonio Caride.

- El grupo de investigación en Psicología Social, Ambiental y de las Organizaciones (PsicoSAO), constituido y reconocido como grupo consolidado en el Departamento de Psicología Social de la Facultad de Psicología en la Universidad

\subsection{The OcioGune network and its research teams}

The network of OcioGune research teams, lead by Dr. Manuel Cuenca, currently Professor Emeritus of the University of Deusto, brings together seven research team specialized in the study of leisure and related themes, fostering cooperative research in this field of knowledge, that the so-called project RESORTES is one of its leading exponents (Caride, Fraguela \& Varela, 2014). The point of confluence of groups integrating it lies in adherence to the principles of humanist leisure and recognition of the contribution of the leisure to human development (social and personal). Each team is specialized in different themes, addressed from different approaches and disciplines (Education, Sociology, Psychology, Geography, Economy, Science of Physical Activity and Sport, etc.) that guarantee the complementarity of their subjects and the multi-inter-discipline character with which the network was conceived. The members of the network, who participated from the beginning in its constitution, design and implementation of the Proyecto RESORTES are:

- The research team in Social Pedagogy and Environmental Education (SPEE-interea), from the Department of Theory of Education, History of Education and Social Pedagogy the Education Sciences Faculty of the University of Santiago de Compostela, is recognized as a competitive group for reference in the $\mathrm{Ga}$ lician University system, whose coordinatorIP is Dr. José Antonio Caride.

- The Group's research in Social Psychology, Environmental Organizations (PsicoSAO), established and recognized as a consolidated group in the Department of Social Psychology at the Faculty of Psychology at the University of Barcelona. It's an interdisciplinary team, where the main investigator is Dra. Nuria Codina.

- The research equipment for educational policy and economic education through life, the promotion of the autonomy of the elderly, elearning sources and social development (FORMADESA. THE - 2) created in the Faculty of Humanities and Education of the Uni- 
de Barcelona. Se trata de un equipo interdisciplinar, del que es investigadora principal la Dra. Nuria Codina.

- El equipo de investigación sobre políticas socioeducativas y económicas para la educación a la largo de toda la vida, la promoción de la autonomía de las personas mayores, soportes e-learning y el desarrollo social (FORMADESA.THE-2) constituido en la Facultad de Humanidades y Educación de la Universidad de Burgos, del que es investigadora principal la Dra. Carmen Palmero.

- El equipo de investigación que sobre Ocio y Desarrollo Humano se adscribe al Instituto de Estudios de Ocio de la Universidad de Deusto en su campus de Bilbao, con una línea de investigación reconocida en torno al Ocio como experiencia personal y fenómeno social, de la que es su investigadora principal la Dra. Cristina Ortega.

- El grupo de investigación en Actividad Física y Deporte en el Espacio y Tiempo de Ocio (AFYDO), en el marco de la educación en valores, constituido en el Departamento de Ciencias de la Educación de la Facultad de Letras y de la Educación de la Universidad de La Rioja, siendo su investigadora principal la Dra. Ana Ponce de León Elizondo.

- El grupo de investigación en Intervención Socioeducativa (Contextos-ISE), adscrito al Departamento de Teoría de la Educación y Pedagogía Social en la Facultad de Educación de la Universidad Nacional de Educación a Distancia (UNED), dirigido por la Dra. Gloria Pérez Serrano.

- El grupo de investigación LOCSUS (Local Sustanability), vinculado al Área IV de Cohesión Social del Instituto de Desarrollo Local (LOCSUS-IIDL) de la Universidad de Valencia, siendo su investigador principal el Dr. Joan Noguera.

A estos grupos se ha añadido, en 2014, el de lnvestigación en Acción Socioeducativa, del Departamento de Educación y Psicología Social, adscrito a la Facultad de Ciencias Sociales de la Universidad Pablo de Olavide, del que es su investigador principal el Dr. Luís Vicente Amador.

La articulación de los Grupos de Investigación de la Red, de la que participan más de 120 perso- versity of Burgos, whose principal researcher is Dra. Carmen Palmero.

- The research team on Leisure and Human Development from the Institute of Studies of Leisure of the University of Deusto in Bilbao, with a recognized research work line on leisure as a personal experience and social phenomenon, whose main researcher is Dra. Cristina Ortega.

- The group for research in Physical Activity and Sport in Time and Space for Leisure (AFYDO), in the framework of the education in values, constituted by Department of Sciences of the Education of the Faculty of Letters and the Education of the University of $\mathrm{La}$ Rioja, being its main researcher Dra. Ana Ponce de León Elizondo.

- The Socio-Educational Intervention (contextsISE) research group, from the Department of Theory of Education and Social Pedagogy at the Faculty of Education of the National University for Distant Learning (UNED), directed by Dra. Gloria Pérez Serrano.

- The LOCSUS (Local Sustainability) research group, linked to the Area IV of Social Cohesion of the Institute for Local Development (LOCSUS-IIDL) of the University of Valencia, being its main researcher Dr. Joan Noguera.

To these groups were added, in 2014, the one of research on Socio-educational Action, of the Department of Education and Social Psychology, from the Faculty of Social Sciences of the Pablo de Olavide University, whose main researcher is Dr. Luís Vicente Amador.

The articulation of the Research Groups of the network, involving more than 120 people - more than 400 if we take into account its "external collaborators" - as teacher and researcher at their respective universities (University professors and Entitled University teachers, Doctors hired and Assistants, Associates, university professors' trainees, or similar), has allowed a wide diversified and continuous projection of the network OcioGune on other networks, groupings, associations, societies, institutes, groups, etc. scientific, based in five continents, encouraged by the desire to increase at a quantitative and qualitative based the

[ 154 ] JOSÉ ANTONIO CARIDE GÓMEZ Y RAÚL FRAGUELA-VALE 
nas -más de 400 si se tienen en cuenta sus "colaboradores externos"- como personal docente e investigador en sus respectivas Universidades (Catedráticos y Profesores Titulares de Universidad, Contratados Doctores y Ayudantes, Profesores Asociados, Becarios de Formación de Profesorado Universitario, o similares), ha permitido una amplia, diversificada y continuada proyección de la Red OcioGune en otras redes, agrupaciones, asociaciones, sociedades, institutos, grupos, etc. científicos, con sede en los cinco continentes, alentadas por el deseo de aumentar en términos cuantitativos y cualitativos la cooperación entre los equipos de investigación que conforman la Red, generando sinergias que se concreten en formas de investigación innovadoras y creativas... en un marco de encuentro, intercambio, reflexión y acción conjunta en torno al ocio y sus realidades. Buena parte de las actuaciones de la Red, en clave de pasado y futuro, están accesibles en la web http://www.resortesociogune.net/.

\subsection{El proyecto coordinado RESORTES: una investigación construida en red}

Una de las principales concreciones del quehacer investigador colaborativo que promueve la Red OcioGune, toma como referencia el proyecto de investigación coordinado que tiene como título principal "De los tiempos educativos a los tiempos sociales: la construcción cotidiana de la condición juvenil en una sociedad de redes", al que se nombra haciendo uso del acrónimo RESORTES. Un proyecto financiado en el marco del Plan Nacional de I+D+i por la Secretaría de Estado de Investigación, Desarrollo e Innovación, adscrita al Ministerio de Economía y Competitividad (con los códigos EDU2012-39080-C07-00 a 07), en su convocatoria de 2012-2015, contando con la aportación de los Fondos Europeos FEDER.

El proyecto estudia las interacciones entre la variable tiempo y los colectivos sociales a los que toma como referencia (en este caso los jóvenes que cursan la Enseñanza Secundaria Postobligatoria en España), con la intención de satisfacer un objetivo general común a los siete subproyectos que participan del proyecto coordinado: estudiar la naturaleza y alcance de los tiempos educativos y sociales en la construcción cotidiana de la con- cooperation between teams that make up the network, generating synergies that will be translated into innovative and creative forms of research... in a context of meeting in exchange, reflection and joint action based on leisure and their realities. Much of the activities of the Network, for past and future, are accessible on the website http://www.resortesociogune.net/

\subsection{The coordinated project RESORTES: a built in network research}

One of the main concretions of collaborative research endeavour that promotes the OcioGune network, referenced in the coordinated research project which has as its main title "from educational to social times: the daily construction of the youth condition in a network society", referred by the acronym RESORTES. A project founded in the framework of the National Plan of R\&D by the Secretariat of State for Research, Development and Innovation, from the Ministry of Economy and Competitiveness (with the codes EDU2012-39080-C07-00-07), in its 2012-2015 call with the contribution of the European FEDER funds.

The project studies interactions between the variable time and social collectives taking as reference (in this case young people on the postcompulsory Secondary Education in Spain), intending to meet a general common objective to the seven sub-projects involved in the coordinated project: studying the nature and scope of educational and social time in the daily construction of the juvenile condition analysing how and to what extent they affect the lives of young people 
dición juvenil, analizando de qué forma y en qué grado inciden en la vida de jóvenes pertenecientes a distintos contextos y realidades, identificando sus problemáticas específicas y las alternativas que deberán adoptarse para contribuir al desarrollo integral de su personalidad y al más pleno ejercicio de sus derechos cívicos.

El logro de este objetivo ha supuesto un avance importante en relación a investigaciones previas, promovidas y realizadas por los grupos que integran la Red Ociogune, no sólo en lo que comporta de dar continuidad y ampliar la investigación desde la Educación Primaria (EP) y Secundaria Obligatoria (ESO) a la Educación Secundaria postobligatoria (BachiIlerato, Formación Profesional, Enseñanzas Especiales, etc.), con su prolongación en el análisis de los procesos de socialización juvenil, sino también por el potencial complementario, multi e interdisciplinar que caracteriza el proyecto de investigación RESORTES: una aportación novedosa en el conocimiento científico existente en España y a nivel internacional sobre esta temática en relación al estudio de los tiempos educativos y sociales.

La interacción entre los distintos subproyectos y los equipos que se responsabilizan de su realización, ha permitido profundizar en la revisión de la literatura y del estado de la cuestión del tema objeto de estudio, de las perspectivas metodológicas con las que se abordan y de sus aplicaciones prácticas a otras realidades, incrementando las opciones en la transferencia de conocimiento y en sus niveles de internacionalización.

Para garantizar la necesaria articulación y colaboración de los equipos adscritos a las diferentes Universidades, se habilitaron recursos presenciales y virtuales, haciendo uso de sistemas de comunicación audiovisual en tiempo real. De acuerdo con el plan de trabajo previamente diseñado se desarrolló una estructura que permitiera conjugar la participación de todos los equipos que integran el proyecto (así como de la mayoría de sus investigadoras e investigadores), con la necesaria flexibilidad y eficiencia que requiere la frecuente $y$ continua toma de decisiones en procesos metodológicos tan complejos como los que se activaron con este proyecto. De ellos damos cuenta, sintéticamente, en lo que sigue describiendo las secuencias, procedimientos y recursos más rele- belonging to different contexts and realities, identifying their specific issues and alternatives to be taken to contribute to the development of their personality and the full exercise of their civic rights.

The achievement of this objective has been an important step forward in relation to previous research, promoted and carried out by groups integrating the Ociogune Network, not only by bringing continuity and expanding research from Primary Education (EP) and Compulsory Secondary Education (ESO) to Post-Compulsory Secondary Education (high school, vocational training, special teachings, etc.), with its extension in the analysis of youth socialization processes, but also because of its complementary potential, its multi and interdisciplinary that characterizes the research project RESORTES: a novel contribution to the existing scientific knowledge of Spain and at an international sphere on this issue in relation to the study of the educational and social times.

The interaction between the various sub-projects and teams responsible for its implementation, enabled us to deepen in the review of the literature and the state of matter of the studied subject, methodological perspectives addressed and their practical applications to other realities, increasing the options in the transfer of knowledge and in their internationalization levels.

To ensure the necessary articulation and the university affiliated team's collaboration, face to face and virtual resources were implemented, using audio-visual communication systems in real time. According to the previously work plan designed, it was developed a structure enabling participation of all teams that integrate the project in order to combine (as well as most of its researchers and researchers) with the necessary flexibility and efficiency that requires frequent and continuous decision making in methodological processes as complex as those activated with this project. In summary, we realize that what continues to portray the sequences, procedures and most relevant resources that used or are using of different teams are:

1. Creation of work-oriented thematic commissions: general coordination, economic

[ 156 ] JOSÉ ANTONIO CARIDE GÓMEZ Y RAÚL FRAGUELA-VALE 
vantes de los que hicieron o vienen haciendo uso los diferentes equipos:

1. Constitución de comisiones temáticas orientadas al trabajo en: la coordinación general, la gestión económica, los procesos metodológicos, la identificación y análisis de buenas prácticas, la transferencia de conocimiento y la comunicación social; además se creó la Red Joven OcioGune, integrada por los investigadores en formación de los equipos de la Red. El deseo de alcanzar los más altos niveles de interacción colectiva supuso, en determinadas circunstancias, redimensionar y dar lugar a nuevas formas de configurar los equipos existentes, como grupos interuniversitarios e interdisciplinares comprometidos con logros específicos, de forma coyuntural o estable. Las comisiones temáticas son la concreción de esta idea. Constituidas por al menos un representante de cada equipo de investigación, con funciones y responsabilidades que implican asumir responsabilidades delegadas en decisiones y actuaciones que afectan al conjunto del proyecto, pasando de trabajar "un equipo junto a otro" a hacerlo en grupos interequipos. La utilización de plataformas virtuales ha posibilitado el uso compartido de la documentación generada en el Proyecto, con agilidad y autonomía por parte de cada equipo, activando servicios de alojamiento de archivos multiplataforma en la nube.

2. Convocatoria y desarrollo de reuniones científicas, simposios, jornadas o seminarios de trabajo presencial en las sedes de los grupos que integran la Red, con una periodicidad semestral. A pesar de las dificultades impuestas por la dispersión geográfica, se han destinado recursos y programado iniciativas orientadas a crear un sentimiento colectivo de pertenencia a la Red OcioGune y de implicación-participación en el proyecto RESORTES.

3. Realización de videoconferencias y reuniones virtuales entre los miembros de las distintas comisiones, tanto de carácter periódico (por ejemplo, en tareas de seguimiento) como puntuales (tratando de dar respuesta a necesidades concretas asociadas a las responsabilidades y al funcionamiento de cada comisión). management, methodological processes, identification and analysis of good practices, knowledge and social communication's transfer; also the OcioGune Young Network was created, composed by training researchers that are part of the teams on the Network. The desire for reaching the highest levels of collective interaction was, under certain circumstances, resized and could lead to new ways to configure existing equipment, such as inter-university and interdisciplinary groups committed to specific achievements, either short-term or stable. The thematic commissions are the realization of this idea. Consisting of at least one representative of each research team, with roles and responsibilities involving responsibilities delegated in decisions and actions that affect the whole project, from working "one team alongside other" to do so in groups inter-teams. The use of virtual platforms has enabled to share the project's generated documentation, with agility and autonomy by each team, by checking cross-platform files in the hosting cloud service.

2. Call for proposals and development of scientific meetings, symposiums, seminars or faceto-face workshops at the offices of the Network's groups every six months. Despite the imposed difficulties due to geographical dispersion, it has been assigned resources and programmed initiatives designed to create a collective sense of belonging to the Network OcioGune and implication-participation in the RESORTES project.

3. Realization of videoconferences and virtual meetings between the commissions' members, both periodic (for example, in tracking tasks) as well as punctual (to respond to specific needs associated with the responsibilities and the performance of each commission).

4. Courses of specialization and other shared activities: members from different teams attended congresses, courses, conferences, seminars... in which, apart from training, contributed to the dissemination of the project's partial results. Moreover, it was boosted the 
4. Realización de cursos de especialización y de otras actividades compartidas: miembros de los diferentes equipos asistieron a congresos, cursos, jornadas, seminarios... en los que, además de formarse, contribuyeron a la difusión de los resultados parciales del proyecto. También se potenció la elaboración y presentación compartida de comunicaciones, la publicación conjunta en revistas especializadas, la docencia en másteres y cursos de doctorado con opción a la codirección de proyectos de Tesis Doctorales y de Trabajos de Fin de Máster, etc., facilitando de esta forma la coordinación de la investigación, la obtención conjunta de resultados, así como su transferencia mediante publicaciones, congresos, etc.

5. Intercambio de investigadores entre las Universidades que configuran la Red OcioGune (actividades de movilidad, destinadas sobre todos a los jóvenes investigadores de sus equipos), lo que ha facilitado la coordinación del Proyecto, la formación permanente y el refuerzo a los equipos de menor tamaño y/o trayectoria, posibilitando su fortalecimiento e incrementando su competitividad.

Desde una perspectiva metodológica, el proyecto RESORTES ha contribuido decisivamente a consolidar la labor investigadora de los grupos que integran la Red OcioGune. En este sentido, el valor añadido del trabajo coordinado -como trabajo en red- ha permitido un avance considerable en sus respectivas líneas de investigación y en el trabajo compartido, en la cualificación científica de sus investigadores (muchos de ellos en período pre o de reciente acceso al postdoctoral) y en las contribuciones realizadas desde sus respectivas comunidades investigadoras al estudio de los tiempos educativos y sociales, tanto a nivel nacional como internacional.

Además, la estructuración de la investigación en red ha permitido: de un lado, una mayor integración de los marcos teóricos-conceptuales, metodológicos y empíricos en los que se fundamentan los estudios del tiempo, en clave educativa y social, con aportes derivados de distintas ciencias y con un afán de construcción interdisciplinar: Psicología, Peda- development and shared presentation of communications, a joint publication in specialized magazines, teaching in masters and doctorate courses sometimes co-managing Doctoral Thesis and Final Dissertations...etc., thus facilitating the coordination of research, the achievement of results as well as their transfer through publications, congresses, etc.

5. Exchange of researchers between universities that make up the Network OcioGune (mobility activities, intended above all to young researchers of their teams), which has facilitated the coordination of the project, the permanent training and reinforcement teams of smaller size or path, making possible its strengthening and increasing their competitiveness.

From a methodological perspective, the project RESORTES has contributed decisively to consolidate the research work of the groups form the Network OcioGune. In this sense, the added value of coordinated work - as work on network enabled a considerable progress in their respective research lines and shared work in the scientific qualification of its researchers (many of them during pre or recent access to the post-doctoral) and contributions from their respective research communities to the study of the educational and social times both nationally and internationally.

In addition, the structuring of the research network has enabled: on one side, a greater integration of theorist-conceptual, methodological and empirical frameworks in which are based the study of time studies, in educational and social contributions arising from different sciences and with by means of interdisciplinary construction: Psychology, Pedagogy, Sociology, History, Social work, Geography, Anthropology, Philosophy, etc.; another, create and strengthen inter-university cooperation with sustainable support, not only from analytical intentions but also from those encouraging a socio-educational action-intervention in various areas of everyday life, public administrations and (local-global) society. 
gogía, Sociología, Historia, Trabajo Social, Geografía, Antropología, Filosofía, etc.; de otro, crear y afianzar la cooperación interuniversitaria con soportes sostenibles, no sólo desde las intenciones analíticas sino también desde las que propicia acción-intervención socioeducativa en diferentes ámbitos de la vida cotidiana, de las Administraciones Públicas y de la sociedad (local-global).

\section{Afrontando el reto: hacia una metodología mixta de investigación}

Nuestra intención no reside en presentar resultados concretos del proyecto RESORTES, sino más bien ilustrar y ejemplificar como a través de una metodología mixta afrontamos los retos derivados de integrar los subproyectos de 6 equipos de investigación, haciéndolos confluir en un proyecto coordinado.

En este sentido, cabe señalar que el diseño de este proyecto contempló, desde sus inicios, una aproximación metodológica integrada y holística basada en la combinación de diversas técnicas, tradicionalmente asociadas con los paradigmas cuantitativo y cualitativo. Debido a la complejidad del objeto de estudio no era posible alcanzar los objetivos de investigación a través un único método o técnica de investigación. De ahí que, partiendo de un posicionamiento teórico basado en la integración metodológica, se formulase la combinación de las perspectivas cuantitativa y cualitativa en las distintas fases del proyecto: desde el diseño de los objetivos y los procedimientos de la investigación, hasta la recogida de los datos, su análisis e interpretación o la presentación de los resultados.

Con todo, optar por una metodología mixta no evita que se establezcan prioridades o elecciones respecto de aquellas técnicas o recursos que son más idóneos a tenor de la realidad social o del tipo de investigación socioeducativa que se promueva, considerando los objetivos, la caracterización básica del problema que se estudia, las variables contextuales a analizar, los supuestos pragmáticos, la participación de los sujetos o los criterios éticos. Admitiendo que existe una amplia gama de instrumentos que están disponibles a la espera de que cada investigador haga un uso específico de ellos, el enfoque y las técnicas deben ser cuidadosamente seleccionados en función

\section{Facing the challenge: towards a mixed re- search methodology}

Our intention is not to present concrete results of the project RESORTES, but rather to illustrate and exemplify how through a mixed methodology, we face the challenges arising from integrating six sub-projects research teams, making them converge on a coordinated project.

In this regard, it should be noted that the design of this project included, since its inception, an integrated methodological and holistic approach based on the combination of different techniques, traditionally associated with the quantitative and qualitative paradigms. Due to the complexity of the object of study, it was not possible to achieve the research aims through a single research method or technique. So that, on the basis of a theoretical positioning based on methodological integration, quantitative and qualitative perspectives combination in the various phases of the project were formulated: from the design of research aims and procedures, data collection, its analysis and interpretation or results presentation.

However, to chose a mixed methodology does not avoid the development of priorities or choices regarding those techniques or resources most suitable according to the social reality or the type of socio-educational research promoted, considering the objectives, basic characterization of the studied problem, contextual variables to analyse, the pragmatic cases, participation of the subjects or the ethical criteria. Assuming that there is a wide range of available tools ready to be specifically used by every researcher, the approaches and techniques must be carefully selected depending of each aspect or dimension - either specific or general - intended to investigate. We present now this selection and techniques integration project: initially through the description of the used tools and, later, the designs that oriented the methodological integration.

Taking into account the RESORTES project, that in a competitive call for proposals to which it is linked is defined as "coordinated", a series of basic procedures were adopted (shared by all the research teams) with a dual purpose: on the one 
de cada aspecto y/o dimensión -ya sea específica o general- que se pretenda indagar. Es este proceso de selección e integración de técnicas el que relatamos a continuación: inicialmente mediante la descripción de los instrumentos utilizados en el proyecto $y$, posteriormente, a través de los diseños que orientaron la integración metodológica.

Teniendo en cuenta la modalidad del Proyecto RESORTES, que en la convocatoria competitiva a la que se vincula lo define como "coordinado", se adoptaron una serie de procedimientos básicos, compartidos por todos los equipos de investigación, con una doble finalidad: por un lado, permitir alcanzar los objetivos generales y comunes del proyecto; $y$, por otro, aportar información a cada uno de los subproyectos, facilitando el desarrollo de su línea específica de trabajo. El diseño y validación de los tres primeros instrumentos se realizó a través de la comisión de metodología y el último por la comisión de buenas prácticas; es decir, por una representación delegada de todos los grupos participantes en el estudio, que garantizaron el cumplimiento de las metas o finalidades planteadas. A grandes rasgos, las principales características de cada uno de estos instrumentos, se resumen en:

- Cuestionarios elaborados ad hoc, destinados a captar las percepciones, necesidades, hábitos y expectativas relacionados con la dis- hand, enabling to reach the common and general objectives of the project; and, on the other, providing information to each of the sub-projects, facilitating the development of their specific work line. Design and validation of the first three instruments was carried out through the commission's methodology and the last one by the best practices committee; i.e. by an associate representation of all participants groups in the study, ensuring the goals or purposes achievement. Broadly speaking, the main features of each of these tools are summarized in:

- Ad hoc developed questionnaires, intended to capture the perceptions, needs, habits and expectations related to the distribution and use of times -school, educational and socialof post-compulsory Secondary Education students. In order to select of the sample a simple random sampling stratum "regime of studies" was used (general-especial) and then a proportional affixation to each Autonomous Community. For the general regime group we work with a margin of error of $2.4 \%$ with a confidence level of $95 \%$. Table 1 contains the main data for sample identification.

Tabla 1. Datos de identificación de la muestra de alumnos ( $n=1807)$

\begin{tabular}{|c|c|c|c|c|}
\hline Edad $\bar{\chi}(D T)$ & Sexo (\%) & Titularidad centro (\%) & Régimen (\%) & Estudios (\%) \\
\hline $18,59(1,58)$ & $\begin{array}{l}\text { Chica }(50,3) \\
\text { Chico }(49,7)\end{array}$ & $\begin{array}{c}\text { Público }(76,1) \\
\text { Privado religioso }(17,7) \\
\text { Privado laico }(6,2)\end{array}$ & $\begin{array}{l}\text { General }(95,2) \\
\text { Especial }(4,8)\end{array}$ & $\begin{array}{c}\text { Bachillerato }(61) \\
\text { CF Grado Medio }(26,3) \\
\text { PCPI }(8,3) \\
\text { Música y Danza }(3,7) \\
\text { Otros }(0,7)\end{array}$ \\
\hline
\end{tabular}

Table 1. Identification data of students' sample $(n=1807)$

\begin{tabular}{|c|c|c|c|c|}
\hline Age $\bar{\chi}(\mathrm{DT})$ & Gender (\%) & Centre Name (\%) & Regime (\%) & Studies (\%) \\
\hline 18.59 (7.58) & $\begin{array}{c}\text { Girl (50.3) } \\
\text { Boy (49.7) }\end{array}$ & $\begin{array}{c}\text { Public (76.7) } \\
\text { Private religious (17.7) } \\
\text { Private secular (6.2) }\end{array}$ & $\begin{array}{c}\text { General (95.2) } \\
\text { Special (4.8) }\end{array}$ & $\begin{array}{c}\text { Bachelor's degree (67) } \\
\text { Professional Training (26.3) } \\
\text { "PCPI" (8.3) } \\
\text { Music and dance (3.7) } \\
\text { Other (O.7) }\end{array}$ \\
\hline
\end{tabular}

[ 160 ] JOSÉ ANTONIO CARIDE GÓMEZ Y RAÚL FRAGUELA-VALE 
tribución y el uso de los tiempos -escolares, educativos y sociales- de alumnos y alumnas de Educación Secundaria postobligatoria. Para la selección de la muestra se aplicó un muestreo aleatorio simple en el estrato "régimen de los estudios" (general-especial) y a continuación una afijación proporcional según Comunidad Autónoma. Para el colectivo de régimen general se trabaja con un margen de error del 2,4\% con un nivel de confianza del 95\%. La Tabla 1 recoge los principales datos de identificación de la muestra.

- Un cuestionario diseñado ad hoc para obtener información acerca de las prácticas docentes, las representaciones y las expectativas relacionadas con la organización, distribución y el uso del tiempo escolar por parte del profesorado de Educación Secundaria postobligatoria. Los docentes de los centros escolares que aportaron sujetos a la muestra de alumnos fueron los mismos a los que se aplicó el cuestionario de profesores. Se realizó el cálculo muestral con los mismos criterios que en el caso anterior (alumnado). Para el colectivo de régimen general se trabaja con un margen de error del $4,5 \%$ con un nivel de confianza del $95 \%$. La Tabla 2 recoge los datos de identificación de la muestra del profesorado.
- An ad hoc designed questionnaire for information gathering about teaching practices, representations and expectations related to the organization, distribution and use of school time by the teaching staff of post-compulsory Secondary Education. Teachers in schools that provided subjects to the students' sample were also participants in teachers' questionnaire. The sample calculation was performed with the same criteria as in the previous case (students). For the general regime group we work with a margin of error of $4.5 \%$ with a confidence level of $95 \%$. Table 2 collects data on identification of the teachers' sample.

- An ad hoc questionnaire was developed, in order to capture family practices related to the educational-school times (depending on the way of teaching, the academic calendar and schedules), in its interaction with other educational and social times of families (in relation to leisure, work, interpersonal relationships, the satisfaction of basic needs like sleep, food, rest, reconciliation, care, etc.). The number of families where the questionnaires were applied was established regarding on the size of the sample of students, considering an "experimental" mortality rate

Tabla 2. Datos de identificación de la muestra de profesorado $(n=528)$

\begin{tabular}{|c|c|c|c|}
\hline Edad $\bar{\chi}(D T)$ & Sexo (\%) & Años de experiencia $\chi$ (DT) & Docencia (\%) \\
\hline $47,4(8,72)$ & $\begin{array}{c}\text { Mujer }(52,8) \\
\text { Hombre }(47,2)\end{array}$ & $18,49(9,55)$ & $\begin{array}{c}\text { Bachillerato (42) } \\
\text { CF Grado Medio (30,8) } \\
\text { PCPI (19) } \\
\text { Música y Danza (7) } \\
\text { Otros }(1,2)\end{array}$ \\
\hline
\end{tabular}

Table 2. Identification data of the teachers' sample $(n=528)$

\begin{tabular}{|c|c|c|c|}
\hline Age $\bar{\chi}(\mathrm{DT})$ & Gender (\%) & Years of experience $\chi$ (DT) & Teaching (\%) \\
\hline $47.4(8.72)$ & $\begin{array}{c}\text { Female (52.8) } \\
\text { Male (47.2) }\end{array}$ & 78.49 (9.55) & $\begin{array}{c}\text { Bachelor's degree (42) } \\
\text { Professional Training (30.8) } \\
\text { "PCPI" (19) } \\
\end{array}$ \\
& & $\begin{array}{c}\text { Music and dance (7) } \\
\text { Other (7.2) }\end{array}$ \\
\hline
\end{tabular}


- Un cuestionario elaborado ad hoc, destinado a captar las prácticas familiares relacionadas con los tiempos educativos-escolares (según la modalidad de jornada lectiva, el calendario académico y los horarios), en su interacción con otros tiempos educativos y sociales de los que se ocupan las familias (en relación al ocio, el trabajo, las relaciones interpersonales, la satisfacción de necesidades básicas como el sueño, la alimentación, el descanso, la conciliación, los cuidados, etc.). El número de familias a las que se les aplicaron los cuestionarios se estableció en función del tamaño de la muestra de alumnado, estimando una mortalidad "experimental" de un 60\%, fruto de la experiencia de con procedimientos análogos en investigaciones previas. Finalmente se superó el $40 \%$ estimado, alcanzado un $46,65 \%$ de respuesta de las familias respecto del alumnado. of $60 \%$, form previous researches' experience. Finally the estimated $40 \%$ was exceeded, with a $46,65 \%$ response from students' families.

- Study of cases and identification of good practices in the management of educational (school) times in post-compulsory Secondary Education. 25 cases for in-depth study were selected. The path used for the initial location of these good practices take as reference similar or Municipal

- Education Departments, the Departments of Education of the Autonomous Communities, Educational Renewal Movements and Federations of Parents and Pupils Associations.

Tabla 3. Datos de identificación de la muestra de familias ( $n=843)$

\begin{tabular}{|c|c|c|c|}
\hline Edad $\bar{\chi}(D T)$ & Quien contesta (\%) & Nivel de estudios (\%) & Situación profesional (\%) \\
\hline $49,53(5,54)$ & $\begin{array}{l}\text { Mujer }(70,9) \\
\text { Hombre }(29,1)\end{array}$ & $\begin{array}{c}\text { Ninguno }(1) \\
\text { Primarios }(25) \\
\text { Secundarios }(39,8) \\
\text { Superiores }(34,2)\end{array}$ & $\begin{array}{c}\text { Empleado/a por cuenta ajena }(57,9) \\
\text { Empleado/a por cuenta propia }(14,4) \\
\text { Desempleado/a }(12,2) \\
\text { Atención del hogar }(11,6) \\
\text { Pensionista }(2,9) \\
\text { Jubilado/a }(1)\end{array}$ \\
\hline
\end{tabular}

Table 3. Identification data of the families' sample $(n=843)$

\begin{tabular}{|c|c|c|c|}
\hline Age $\bar{\chi}($ DT) & Who answers (\%) & $\begin{array}{c}\text { Level of education } \\
(\%)\end{array}$ & Professional status (\%) \\
\hline \multirow{3}{*}{49.53 (5.54) } & Female (70.9) & None (1) & Employee (57.9) \\
& Male (29.1) & Primary (25) & Self-employment (14.4) \\
& & Secondary (39.8) & Unemployed (12.2) \\
& & Superior (34.2) & Home's care (17.6) \\
& & Pensioner (2.9) \\
& & Retired (1) \\
\hline
\end{tabular}

- Estudio de casos e identificación de buenas prácticas en la gestión de los tiempos educativos (escolares) en la Educación Secundaria postobligatoria. Se seleccionaron 25 casos para su estudio en profundidad. La vía de acceso utili-
Simultaneous or subsequently to the design and implementation of these instruments, each team was involved in the development of other procedures, affecting the whole project, but specifically linked to the theme of its sub-projects. Among others:

[ 162 ] JOSÉ ANTONIO CARIDE GÓMEZ Y RAÚL FRAGUELA-VALE 
zada para la localización inicial de estas buenas prácticas toma como referencia los Departamentos Municipales de Educación o similares, las Consejerías de Educación de las Comunidades Autónomas, los Movimientos de Renovación Pedagógica y las Federaciones de Asociaciones de Padres y Madres de Alumnos.

Simultánea o posteriormente al diseño y aplicación de estos instrumentos, cada equipo se implicó en el desarrollo de otros procedimientos, que afectan al conjunto del proyecto, pero que están específicamente ligados a la temática de sus subproyectos. Entre otros:

- La realización de entrevistas a 16 jóvenes (16-18 años) para analizar los procesos de socialización y aprendizaje del ocio en períodos transicionales (a cargo del equipo de la Universidad de Deusto).

- La aplicación de una escala de evaluación de la flexibilidad y cohesión familiar_FACES II (OIson, Portner \& Bell, 1982) y de la escala de comunicación familiar_FCS (Olson \& Barnes, 2004), a la totalidad de la muestra, tanto de alumnado $-n=1807-$, como de sus familias $-n=843$ (por parte del equipo de la Universidad de La Rioja).

- La aplicación de la técnica Delphi con informantes clave para determinar los criterios de calidad de las intervenciones que se han de realizar para la inclusión de jóvenes en dificultad social, fundamentalmente en el ámbito del ocio, la formación y el empleo (del que se responsabiliza el equipo de la Universidad Nacional de Educación a Distancia).

- El diseño de un proceso cuasi-experimental para la evaluación de propuestas y experiencias dirigidas a incentivar el comportamiento emprendedor entre los jóvenes (a cargo del equipo de la Universidad de Burgos).

- La realización de grupos de discusión con distintos sectores de la comunidad educativa relacionados con la planificación y organización de los tiempos educativos y escolares. La incorporación de esta técnica tuvo como objetivo interpretar algunos de los resultados obtenidos en los cuestionarios, identificar los principales problemas relacionados con este
- The realization of interviews with 16 young people (16-18 years) to analyse the processes of socialization and leisure learning in transitional periods (by the University of Deusto's team).

- The application of a scale of flexibility and cohesion familiar FACES II assessment (Olson, Portner \& Bell, 1982) and the scale of familiar_FCS communication (Olson \& Barnes, 2004), all of the sample, both student $-n=$ 1807- and their families - $n=843$ - (by the team of the University of La Rioja).

- The application of the Delphi technique with key informants to determine the criteria for quality of interventions that needs to be carried out for the inclusion of youth in social difficulty, mainly in the field of leisure, the training and employment (by the UNED team).

- The design of a quasi-experimental process for the evaluation of proposals and experiences aimed at encouraging entrepreneurial behaviour among young people (by the University of Burgos).

- Conducting discussion groups with different sectors of the educational community, related to the planning and organization of educational and school time. The incorporation of this technique aimed to interpret some of the questionnaires obtained results, to identify the main problems related to this area, to know the point of view and interests of the educational community groups and to develop a prospective approach on trends in the middle and long term regarding socio-educational-school times. This technique was applied to six groups of key informants: with teachers in post-compulsory Secondary Education belonging to different groups (unions, groups of educational renewal, etc.); with parents and representatives of parent associations AMPAS; other decision-makers of decisions (political and technical) from the Educational Administrations; with different social agents whose opinion may be relevant (researchers in the field of leisure and school organization; with researchers in the field of Psychology, Sociology, Chronobiology and Medicine; entrepreneurs of leisure services; 
ámbito, conocer el punto de vista y los intereses de los distintos colectivos que integran la comunidad educativa y realizar una aproximación prospectiva sobre las tendencias a medio y largo plazo en la relación tiempos educativos-escolares- sociales. Se aplicó esta técnica a seis colectivos de informantes clave: con docentes de Educación Secundaria postobligatoria pertenecientes a distintos colectivos (sindicatos, grupos de renovación pedagógica, etc.); a padres y representantes de AMPAS; otro a encargados de la toma de decisiones (políticos y técnicos) desde las Administraciones educativas; con distintos agentes sociales cuya opinión puede ser relevante (investigadores en el campo del ocio y de la organización escolar; a investigadores en el campo de la Psicología, Sociología, Cronobiología y la Medicina; empresarios de servicios de ocio; etc.); $y$ a estudiantes que cursan esta etapa educativa. En la aplicación de esta técnica participaron los equipos de las Universidades de Santiago de Compostela (en el marco del sistema educativo), Burgos (con agentes sociales y económicos relacionados con el emprendimiento), Deusto (con responsables de gestión de espacios de ocio juvenil, familias, responsables públicos y expertos), La Rioja (con jóvenes, familias y profesionales del ocio) y la UNED (con jóvenes en riesgo y agentes sociales que trabajan con ellos).

- El análisis de dietarios, semanarios y/o agendas personales realizados por alumnos/as de Bachillerato y Formación Profesional en los que reflejaron las secuencias cronológicas de los diferentes tiempos que articulan el día y la semana lectiva, los períodos de actividad y descanso, el fin de semana, los períodos vacacionales, etc. A través de análisis de contenido se pretenden sistematizar sus aportes como un procedimiento relevante en el estudio de los ritmos temporales y su incidencia en la vida cotidiana, en este caso de los jóvenes que cursan la Educación Secundaria postobligatoria. En este proceso metodológico se implicaron los equipos de las Universidades de Santiago de Compostela, Deusto y La Rioja. El grupo de investigación de la Universidad de Barcelona también utilizó ver- etc.); and with students on this educational stage. For the application of this technique teams from the universities of Santiago de Compostela (in the framework of the education system), Burgos (with social and economic agents related to entrepreneurship), Deusto (with management of youth leisure, families, public officials and experts), La Rioja (with young people, families and professionals of the entertainment) and the UNED (with at-risk youth and stakeholders who work with them).

- Analysis of dietary, weeklies or personal agendas made by students of High School and vocational training in which the chronological sequences of the different times that day and the teaching week, periods of activity and rest, weekend, holiday periods, etc were reflected. Through content analysis it is intended to systematize their contributions as an important procedure in the study of temporal rhythms and its impact on everyday life, in this case young people who attend the postcompulsory Secondary Education. In this methodological process teams from the universities of Santiago de Compostela, Deusto and La Rioja are involved. The research group of the University of Barcelona will also use versions or adaptations of so-called "time budgets" (Neulinger, 1981) and of the Twenty-Statments (Kuhn \& MacPartland, 1967).

As explained before, in order to describe the methodological integration of those tolls we will use the classification of research approaches in mixed methods proposed by Teddlie \& Tashakkori (2003), but also the works of Camerino, Castañer \& Anguera (2012) and Castañer, Camerino \& Anguera (2013) that develop and exemplify each of the designs variants with real research in the Social Sciences field specifically in the context of Movement Sciences (Physical Activity and Sport). From a general perspective, the project RESORTES uses a quantitative $>$ qualitative design, given that the central axis of the research are the three questionnaires applied to representative samples for all over Spain. This general orienta-

[ 164 ] JOSÉ ANTONIO CARIDE GÓMEZ Y RAÚL FRAGUELA-VALE 
siones y/o adaptaciones de los denominados "presupuestos del tiempo" (Neulinger, 1981) y del Twenty-Statments (Kuhn \& MacPartland, 1967).

Como ya se ha expuesto, para describir la integración metodológica de estos instrumentos utilizaremos la clasificación de enfoques de investigación en métodos mixtos propuesta por Teddlie \& Tashakkori (2003), pero también los trabajos de Camerino, Castañer \& Anguera (2012) y Castañer, Camerino \& Anguera (2013) que desarrollan y ejemplifican cada una de las variantes de los diseños con investigaciones reales en el ámbito de las Ciencias Sociales, concretamente en el contexto de las Ciencias del Movimiento (Actividad Física y Deporte). Desde una perspectiva general, el proyecto RESORTES utiliza un diseño cuantitativo -> cualitativo, ya que el eje central de la investigación son los tres cuestionarios aplicados en las muestras representativas para el conjunto del territorio español. Esta orientación general da lugar a dos diseños distintos, uno convergente y otro secuencial.

El primero se categoriza dentro de los diseños incrustados de dominancia, concretamente en los modelos correlacionales, ya que los datos cualitativos están anidados en el diseño cuantitativo. Se trabaja con datos cuantitativos, pero también con los cualitativos secundarios que estaban correlacionados con los primeros, como un complemento a lo largo de la investigación. De esta forma se realiza una interpretación de los datos centrada en la información cuantitativa, utilizando por añadidura la cualitativa. Un ejemplo de este diseño son las actividades de ocio preferidas por el alumnado, los motivos de su realización y la gestión de los espacios de ocio. En el cuestionario aplicado a los alumnos hay varios ítems que solicitan información sobre estas cuestiones, siendo el eje principal en el análisis de datos. Sin embargo, en las entrevistas en profundidad, realizadas a alumnos por los investigadores de la Universidad de Deusto, se incluyen otras preguntas relacionadas con las actividades de ocio que realizan los jóvenes: 1) ¿Cuáles son las prácticas de ocio que más te gustan o interesan?, 2) ¿Cuáles son, de todas ellas, las que consideras más importantes para ti?, 3) ¿Por qué esas prácticas son tan importantes para tí?. Con relación a las actividades de ocio más valiosas: 4) ¿Dónde y con quién practi- tion results in two different designs, a converged and a sequential one.

The first is categorized within dominant embedded designs, specifically in the correlational models, given that qualitative data are allocated at the quantitative design. We work with quantitative data, but also with its correlated qualitative side, as a complement during the investigation. In this way an interpretation of data focused on the quantitative information, also using the qualitative is performed. Examples of those designs are the leisure activities preferred by students, the reasons for its realization and the management of leisure areas. In the students' questionnaire, there are several items requesting information on these issues, being the main axis in data analysis. However, the in-depth interviews, made to students by researchers from the University of Deusto, include other questions related to leisure activities of young people: 1) What are the leisure practices that you like more or you are more interest at? 2) What from all of them do you consider most important for you? 3) Why are those practices so important for you? Regarding the most valuable leisure activities: 4) Where and with whom do you practice these valuable leisure activities? 5) that place Of what kind is it?, and How is it organized? 6) How are you involved in that leisure area management?, What is your role? The answers to these questions provide a potential explanatory data to those questionnaires enriching and giving greater depth to the data analysis on these topics.

The second design used in the RESORTES project belongs to the explanatory sequential designs, specifically the follow-up model, which focuses on quantitative data, used to detect significant differences between groups, including individuals with end results or in the case of unexpected results. According to the quantitative results, qualitative instruments created from issues tracked as those of special interest in the first design phase. In this case, the key study themes were incorporated into more than one questionnaire, in order to contrast the views of different groups on them (table 1). This first stage cannot be strictly considered mixed methodology, since it integrates information from a single instrument (questionnaire) in a data triangulation aiming to identify the simi- 
cas esas actividades de ocio valiosas?, 5) Ese espacio ¿De qué tipo es?, y ¿Cómo se organiza?, 6) ¿Cómo participas tú en la gestión de ese espacio de ocio?, ¿Cuál es tu papel?. Las respuestas a estas preguntas ofrecen un potencial explicativo a los datos de los cuestionarios que enriquece y da mayor profundidad al análisis de la información sobre estas temáticas.

El segundo de los diseños utilizado en el proyecto RESORTES pertenece a los diseños explicativos secuenciales, concretamente al modelo de seguimiento, que se centra en los datos cuantitativos, a los que se recurre para detectar diferencias significativas entre grupos, entre individuos con resultados extremos o en el caso de resultados inesperados. En función de los resultados cuantitativos se diseñaron los instrumentos cualitativos, construidos a partir de cuestiones sobre las que se pretende hacer un seguimiento por considerarlas de especial interés en la primera fase del diseño. En este caso, los temas clave del estudio fueron incorporados a más de un cuestionario, larities and differences between the key groups and getting information for the design of some of the qualitative instruments referred to in the research's sequential design.

Tabla 4. Triangulación de datos: algunos temas clave y colectivos informantes (cuestionarios)

\begin{tabular}{|l|l|}
\hline Temas clave & Participantes \\
\hline Modalidad de jornada lectiva preferida & Alumnos, padres y profesorado \\
\hline Tiempo dedicado a estudiar & Alumnos, padres y profesorado \\
\hline Percepción de salud y calidad de vida & Alumnos y padres \\
\hline Nivel de actividad física & Alumnos y padres \\
\hline Satisfacción con la vida familiar & Alumnos y padres \\
\hline Estudios y mercado laboral en el futuro & Alumnos, padres y profesorado \\
\hline Preocupaciones por la realidad del alumnado & Padres y profesorado \\
\hline
\end{tabular}

Table 4. Data triangulation: some key issues and collective informants (questionnaires)

\begin{tabular}{|l|l|}
\hline Key issues & Participants \\
\hline Favourite school day & Students, parents and teachers \\
\hline Time spent studying & Students, parents and teachers \\
\hline Perception of health and quality of life & Students and parents \\
\hline Level of physical activity & Students and parents \\
\hline Satisfaction with family life & Students and parents \\
\hline Studies and labour market in the future & Students, parents and teachers \\
\hline Concerns about the students' reality & Parents and teachers \\
\hline
\end{tabular}

[ 166 ] JOSÉ ANTONIO CARIDE GÓMEZ Y RAÚL FRAGUELA-VALE 
al objeto de contrastar la opinión de distintos colectivos sobre ellos (tabla 1). Esta primera etapa no puede considerarse metodología mixta en sentido estricto, ya que integra la información de un mismo instrumento (cuestionario) en una triangulación de datos que tiene como finalidad identificar las coincidencias y divergencias existentes entre los colectivos clave y obtener información para el diseño de algunos de los instrumentos cualitativos que se contemplan en el diseño secuencial de la investigación.

Cuando se detectan diferencias significativas entre los colectivos de participantes con valores extremos y/o divergencias importantes, se incorporan al diseño de los instrumentos cualitativos en una segunda fase del diseño. Por ejemplo, sobre la cuestión del tiempo dedicado a estudiar, se encontraron coincidencias entre el alumnado y sus padres, pero fuertes divergencias de ambos colectivos con el profesorado (cuadro 1).

Cuadro 1. Datos de los cuestionarios de alumnado, padres y profesorado sobre el tiempo de estudio

\footnotetext{
Media tiempo dedicado a estudiar: los alumnos informan de una media de 11,29 minutos y los padres de 143,13 minutos, en ambos casos con desviaciones típicas bastante elevadas. No existen diferencias significativas entre la opinión de los hijos y de los padres en cuanto a esta cuestión. Aunque los padres tienden a sobrevalorar el tiempo de estudio de sus hijos, la diferencia no es significativa.
}

Valoración del tiempo de estudio: "está bien": 62,7\% los alumnos y 57,9\% los padres. Existe una correlación positiva altamente significativa entre padres e hijos en la valoración del tiempo que dedican a estudiar los adolescentes.

Los profesores creen que sus alumnos dedican una media de 37,16 minutos al día a estudiar y hacer las tareas de clase y que deberían emplear al menos 56,37 minutos. Además, valoran mayoritariamente $(79,4 \%)$ el tiempo de estudio de su alumnado como "escaso".

Para Ivankova (2014), cuando los instrumentos cuantitativos generan datos inconsistentes (por contradictorios) o sorpresivos (porque se oponen a la teoría existente), es necesario hacer un seguimiento de estos datos para garantizar su correcta interpretación. En el proyecto RESORTES, en el guión
When significant differences between the groups of participants with extreme values and/or important divergences are detected, those are added to the design of qualitative instruments for its second phase. For example, about the question of the time devoted to study, we found matches between students and their parents, but strong differences from both groups with the teaching staff (chart 1 )

Chart 1. Data from the questionnaire of students, parents and teaching staff on study time

Average time spent studying: students report an average of 111.29 minutes and the parents of 143.13 minutes, in both cases with fairly high standard deviations. There are no significant differences between the opinion of children and parents on this issue. Although parents tend to overestimate their children study time, the difference is not significant.

Assessment of study time: "okay": 62.7\% students and $57.9 \%$ parents. There is a highly significant positive correlation between parents and sons in the assessment of the teenagers' time spent studying.

Teachers believe that students spend an average of 37.16 minutes per day studying and doing home-works and that they should employ at least 56.37 minutes. In addition, they value mostly (79.4\%) the time study of their students as "insufficient".

According to Ivankova (2014), when the quantitative tools generate inconsistent data (contradictory) or surprising (opposed to the existing theory), it is necessary to keep track of this data to ensure its correct interpretation. In the RESORTES project, on the screenplay for the students discussion groups developed by the team of the University of Santiago de Compostela, a question about the time of the study was added (chart 2), which it was also included into the parents and teaching staff discussion groups, in order to generate an interpretation of the quantitative information of the study participants. 
de los grupos de discusión del alumnado desarrollados por el equipo de la Universidad de Santiago de Compostela, se incorpora una cuestión sobre el tiempo de estudio (cuadro 2), que también se incluye de forma equivalente en los grupos de discusión de los padres y el profesorado, para tener una interpretación de la información cuantitativa de los propios participantes en el estudio.

Cuadro 2. Preguntas del grupo de discusión del alumnado sobre su tiempo de estudio derivadas de los resultados inesperados obtenidos en los cuestionarios de alumnado, padres y profesorado

Los datos del cuestionario indican que dedicáis 1 h y 50 minutos de media al día a estudiar y hacer las tareas de clase y que ese tiempo "está bien". Vuestros padres, aunque creen que estudiáis media hora más de lo que vosotros decís, coinciden bastante con vuestras opiniones sobre este tema. También valoran que el tiempo que dedicáis a estudiar "está bien". Sin embargo, vuestros profesores estiman que estudiáis unos 37 minutos al día y que este tiempo es insuficiente: ¿Cómo valoráis estos datos? ¿Por qué creéis que existen estas diferentes percepciones?

El análisis de la información cualitativa permite conocer la explicación de cada colectivo a sus propias respuestas y también la interpretación que hacen de la opinión de los otros grupos de informantes, lo que resulta clave para el análisis y la discusión de los datos por parte de los investigadores; siguiendo con el ejemplo anterior, respecto a la temática del tiempo dedicado a estudiar, diversificando y dando mayor profundidad a las justificaciones iniciales de las divergencias encontradas. La articulación de los procedimientos de investigación del proyecto RESORTES se sitúa en el contexto de los métodos mixtos, no sólo desde la perspectiva del análisis de resultados, sino de todo lo que afecta al proceso de indagación: desde el planteamiento del problema hasta la difusión de los resultados, pasando por la elaboración de la memoria y del plan de trabajo, el diseño y la aplicación de los instrumentos, la recogida y el análisis de los datos, la interpretación de sus evidencias, la escritura y la lectura de sus "textos", etc.
Chart 2. Questions from the students' discussion group on their study time derived from the unexpected results of questionnaires from students, parents and teachers

The questionnaire data indicate that you devote an average of 7 hour and 50 minutes a day to study and do the homework and that that time "is good". Your parents, although they believe that you study half an hour more of what you say, quite agree with your opinions on this subject. They also value the time that you dedicate to study "is ok". However, your teachers estimate that you study a 37 minutes a day and that this time is not enough: How do you value these data? Why do you think that there are these different perceptions?

The analysis of the qualitative information allows each group to give an explanation to their own answers and also their interpretation of the other informant groups' opinions, which is key to the research's for its data analysis and discussion; for example, regarding the time spent studying, diversifying and giving greater depth to the initial justifications of the differences found. The creation of the procedures for the research project RESORTES lies in the context of mixed methods, not only from the perspective of the analysis results, but regarding all that affects the inquiry process: from the problem approach to the results dissemination, through the development of the memory and of the work plan, the instruments design and implementation, the data collection and analysis, the evidence interpretation, writing and reading their "texts", etc.

[ 168 ] JOSÉ ANTONIO CARIDE GÓMEZ Y RAÚL FRAGUELA-VALE 


\section{Conclusión}

Siendo uno de sus pretextos abrir el conocimiento científico a nuevos temas y problemas en el estudio de los tiempos educativos y sociales de los jóvenes, el proyecto RESORTES ejemplifica una apuesta decidida de los investigadores que participan de sus iniciativas por las metodologías mixtas: un propósito con el que se pretende alcanzar la máxima congruencia posible entre los saberes compartidos y las prácticas metodológicas que nacen del diálogo paradigmático y la integración de perspectivas, de la estima por la pluralidad y del reto que supone afrontar sus complejidades en una sociedad de redes.

De ahí que no solo se aspire a que los "informantes", considerados como los sujetos y no únicamente como el objeto de la investigación, den respuesta a las cuestiones que se les plantean a través de distintos procedimientos o técnicas (cuestionarios, escalas, grupos de discusión, etc.). Además se trata de hacerlos partícipes de sus resultados y, tanto como sea factible, de la interpretación de los datos que ellos mismos han proporcionado a través de instrumentos cuantitativos haciendo uso de métodos cualitativos. $\mathrm{O}$, más aún, posibilitando que al paso del tiempo, siendo informados de las contribuciones que han hecho al desarrollo del proyecto, puedan poner en valor sus aportes para inducir mejoras que transformen positivamente sus realidades cotidianas.

La educación del ocio, las políticas integrales depara-con los jóvenes, la educación en valores cívicos o la puesta en marcha de procesos de investigación-acción-participativa en los centros educativos o en los espacios comunitarios, son algunas de las alternativas que siempre deben estar a su alcance, que la Pedagogía Social y la Educación Social reivindican para el presente histórico y con una inequívoca vocación de futuro.

\section{Conclusion}

As one of their pretexts is to open scientific knowledge to new issues and problems in the study of the educational and social times of young people, the project RESORTES exemplifies a firm commitment of the researchers participating in its initiatives to mixed methodologies: a purpose which aims to achieve the highest possible congruence between the shared knowledge and methodological practices coming from a paradigmatic dialogue and the integration of perspectives, the esteem for plurality and the challenge of tackling the complexities in a society of networks.

That is why it not only aspires to get an answer from "informants", considered as subjects and not only as the object of research, on issues that arise through different procedures or techniques (questionnaires, scales, groups of discussion, etc.). It is also make them partakers of their results and, if possible, of the data interpretation that they have provided through quantitative tools by means of qualitative methods. Or, even more, allowing that with time, being informed of the contributions that made to the development of the project, they can put in value its contributions to boost improvements that can positively transform their daily lives.

Education for leisure, comprehensive policies for-from-with young people, education in civic values or the making up of research- action- participatory-processes in schools or in the community areas, are some of the alternatives that should always be within your reach, that are claimed by Social Pedagogy and Social Education to the historical present and with a clear vocation for the future. 


\section{Bibliografía / Referencias Bibliográficas}

Bazeley, P., \& Kemp, L. (2012). Mosaics, Triangles, and DNA: Metaphors for Integrated Analysis in Mixed Methods Research. Journal of Mixed Methods Research, 6 (1), 55-72. doi: 10.1177/1558689811419514

Bergman, M. M. (2011). The good, the bad, and the ugly in mixed methods research and design. Journal of Mixed Methods Research, 5 (4), 271-275. doi: 10.1177/1558689811433236

Bericat, E. (1998). La integración de los métodos cuantitativo y cualitativo en la investigación social: significado y medida. Barcelona: Ariel.

Camerino, O., Castañer, M., \& Anguera, M. T. (2012). Mixed methods research in the movement sciences: Case studies in sport, physical education and dance. New York: Routledge.

Caride, J.A, Fraguela, R., \& Varela, L. (2014). Investigación en Red: los tiempos educativos y sociales, en clave de ocio y desarrollo humano. Investigación. Cultura, Ciencia y Tecnología (Instituto de Cultura, Ciencia y Tecnología, 6 (11), 14-22.

Castañer, M., Camerino, O., \& Anguera, M. T. (2013). Métodos mixtos en la investigación de las ciencias de la actividad física y el deporte. Apunts. Educación Física y Deportes, 112, 31-36.

Curry, L. A., O'Cathain, A., Clark, V. L. P., Aroni, R., Fetters, M., \& Berg, D. (2O12). The Role of Group Dynamics in Mixed Methods Health Sciences Research Teams. Journal of Mixed Methods Research, 6 (1), 5-20. doi: $10.1177 / 1558689811416941$

Denzin, N. K., \& Y. S. Lincoln (2012). Introducción general: la investigación cualitativa como disciplina y como práctica. En: N. K. Denzin \& Y. S. Lincoln (coords.). El campo de la investigación cualitativa (pp. 43-101). Barcelona: Gedisa.

Flick, U. (1992). Triangulation revisited: Strategy of or alternative to validation of qualitative data. Journal for the Theory of Social Behavior, 35, 175-197.

Flick, U. (2008). Managing quality in qualitative research. London: SAGE.

Flick, U., Garms-Homolová, V., Herrmann, W. J., Kuck, J., \& Röhnsch, G. (2012). “I Can’t Prescribe Something Just Because Someone Asks for It. ..": Using Mixed Methods in the Framework of Triangulation. Journal of Mixed Methods Research, 6 (2), 97-110. doi: 10.1177/1558689812437183

Gómez, J., Latorre, A., Sánchez, M., \& Flecha, R. (2006). Metodología comunicativa crítica. Barcelona: El Roure.

Greene, J. C. (2007). Mixed methods in social inquiry. San Francisco: Jossey-Bass.

Greene, J. C., \& Caracelli, V. J. (2003). Making paradigmatic sense of Mixed Methods practice. En A. Tashakkori \& C. Teddlie (eds.), Handbook Mixed Methods in social and behavioral research (pp. 91-110). Thousand Oaks: Sage.

Gutiérrez, J. (2008). Avances metodológicos contemporáneos en el campo de la investigación en Educación Ambiental. En P. A. Meira \& M. Andrade (coords.). Investigación y Formación en Educación Ambiental: novos escenarios e enfoques para un tempo de cambios (pp. 65-76). Santiago de Compostela: CEIDA.

Habermas, J. (1987). Teoría de la acción comunicativa. I: racionalidad de la acción y racionalización social. Madrid: Taurus.

Harrits, G. S. (2011). More than method?: A discussion of paradigm differences within mixed methods research. Journal of Mixed Methods Research, 5 (2), 150-166. doi: 10.1177/1558689811402506

Howe, K. R. (2012). Mixed Methods, Triangulation, and Causal Explanation. Journal of Mixed Methods Research, 6 (2), 89-96. doi: 10.1177/1558689812437187

Ivankova, N. V. (2014). Implementing Quality Criteria in Designing and Conducting a Sequential QUAN QUAL Mixed Methods Study of Student Engagement With Learning Applied Research Methods Online. Journal of Mixed Methods Research, 8 (1), 25-51. doi: 10.1177/1558689813487945

Johnson, R. B., Onwuegbuzie, A. J., \& Turner, L. A. (2007). Toward a definition of mixed methods research, Journal of Mixed Methods Research, 7(2), 112-133. doi: 10.1177/1558689806298224

Kuhn, T. (1962). The Structure of Scientific Revolutions. Chicago: University of Chicago Press.

[ 170 ] JOSÉ ANTONIO CARIDE GÓMEZ Y RAÚL FRAGUELA-VALE

SIPS - PEDAGOGIA SOCIAL. REVISTA INTERUNIVERSITARIA [1139-1723 (2015) 26, 139-172] TERCERA ÉPOCA 
Kuhn, M. H. \& McPartland, T. S. (1967). An empirical investigation of self-attitudes. En Manis, J. G. \& Meltzer, B. N. (eds.). Symbolic Interaction: A Reader in Social Psychology (pp. 83-92). Boston: Allyn and Bacon (3a ed.).

López-Fernández, O., \& Molina-Azorín, J. (2011). The use of mixed methods research in the field of behavioural sciences. Quality \& Quantity, 45, 1459-1472. doi: 10.1007/s11135-011-9543-9

Martínez, M. (2006). Ciencia y arte en la metodología cualitativa. México: Trillas.

Mertens, D. M. (2007). Transformative Paradigm. Mixed Methods and Social Justice. Journal of Mixed Methods Research, 1 (3), 212-225. doi: 10.1177/1558689813493994

Mertens, D. M. (2011). Mixed methods as tools for social change. Journal of Mixed Methods Research, 5 (3), 195-197. doi: 10.1177/1558689811418095

Mertens, D. M. (2013). Emerging Advances in Mixed Methods: Addressing Social Justice. Journal of Mixed Methods Research, 7 (3), 215-218. doi: 10.1177/1558689813493994

Molina-Azorín, J. F. (2011). The use and added value of mixed methods in management research. Journal of Mixed Methods Research, 5 (1), 7-24. doi: 10.1177/1558689810384490

O'Cathain, A. Murphy, E., \& Nicholl, J. (2008). Multidisciplinary, interdisciplinary, or dysfunctional? Team working in mixed-methods research. Qualitative Health Research, 18 (11), 1574-1585. doi: 10.1177/1049732308325535

Olson, D. H., \& Barnes, H. (2004). Family communication. Minneapolis: Life Innovations.

Olson, D. H. Portner, J., \& Bell, R. Q. (1982). FACES II: Family adaptability and cohesion evaluation scales. St. Paul: Family Social Science, University of Minnesota.

Popkewitz, T. S. (1988). Paradigma e ideología en investigación educativa: las funciones sociales del intelectual. Madrid: Mondadori.

Povee, K., \& Roberts, L. D. (2015). Attitudes toward mixed methods research in psychology: the best of both worlds? International Journal of Social Research Methodology, 18 (1), 41-57. doi: 10.1080/13645579.2013.872399

Shulha, L. M., \& Wilson, R. J. (2003). Collaborative mixed methods research. En A. Tashakkori \& C. Teddlie (Eds.), Handbook Mixed Methods in social and behavioral research (pp. 639-669). Thousand Oaks: Sage.

Teddlie, C., \& Tashakkori, A. (2003). Major issues and controversies in the use of mixed methods in the social and behavioral sciences. En A.Tashakkori \& C. Teddlie (Eds.), Handbook of mixed methods in social \& behavioral research (pp. 3-50). Thousand Oaks: SAGE.

Teddlie, C., \& Tashakkori, A. (2009). Foundations of mixed methods research. Integrating quantitative and qualitative approaches in the social and behavioral sciences. Thousand Oaks: SAGE.

Toulmin, S. (2003). Regreso a la razón: el debate entre la racionalidad y la experiencia y la práctica personales en el mundo contemporáneo. Barcelona: Península.

\section{Notas / Notes}

${ }^{1}$ El texto que presentamos se vincula a un proyecto de investigación cofinanciado por el Fondo Europeo de Desarrollo Regional (FEDER, 2007-2013) y el Ministerio de Economía y Competitividad del Gobierno de España (códigos EDU2O1239080-C07-00 a 07), en el marco del Plan Nacional de 1+D+i: "De los tiempos educativos a los tiempos sociales: la construcción cotidiana de la condición juvenil en una sociedad de redes. Problemáticas específicas y alternativas pedagógico-sociales" (Proyecto coordinado RESORTES, con la participación de las Universidades de Barcelona, Burgos, Deusto, La Rioja, Nacional de Educación a Distancia y Santiago de Compostela).

\section{CÓMO CITAR ESTE ARTÍCULO / HOW TO CITE THE ARTICLE}

Caride Gómez, J. A., \& Fraguela-Vale, R. (2015). Cuando el proyecto se hace método: nuevas perspectivas para la investigación socioeducativa en red. Pedagogía Social. Revista Interuniversitaria, 26 139-172. DOI:10.7179/PSRI_2015.26.06

CUANDO EL PROYECTO SE HACE MÉTODO: NUEVAS PERSPECTIVAS PARA LA INVESTIGACIÓN SOCIOEDUCATIVA EN RED [ 171 ] SIPS - PEDAGOGIA SOCIAL. REVISTA INTERUNIVERSITARIA [1139-1723 (2015) 26, 139-172] TERCERA ÉPOCA 
Fecha de recepción del artículo / received date: $07 . I V .2015$

Fecha de revisión del artículo / reviewed date: 18.IV.2015

Fecha de aceptación final / accepted date: 29.IV.2015

\section{DIRECCIÓN DE LAS AUTORAS/ AUTHORS' ADDRESS}

José Antonio Caride. Facultad de Ciencias de la Educación - campus Vida. 15782 - Santiago de Compostela. Dirección de correo/e-mail: joseantonio.caride@usc.es

Raúl Fraguela Vale. Universidad de A Coruña. Dirección de correo/e-mail: raul.fraguela@udc.es

\section{PERFIL ACADÉMICO / ACADEMIC PROFILE}

José Antonio Caride. Catedrático de Pedagogía Social. Dpto. de Teoría de la Educación, Historia de la Educación y Pedagogía Social de la Facultad de Ciencias de la Educación. Director-IP del Grupo de Investigación en Pedagogía Social y Educación Ambiental (SEPA-interea) de la Universidad de Santiago de Compostela. Coordinador-IP de la Red de Grupos de Investigación en Educación y Formación para la Ciudadania y la Sociedad del Conocimiento (RINEF-CISOC) en el Sistema Universitario Gallego.

Raúl Fraguela-Vale. Doctor en Educación Física por la Universidad de A Coruña. Profesor Titular de Escuela Universitaria en el área de Expresión Corporal de la Facultad de Ciencias de la Educación. Sus principales líneas de investigación son: Educación para el Ocio y Educación Física, tiempos educativos y sociales, actividad física y salud en la infancia, políticas deportivas a nivel local y el juego en la infancia. Pertenece a los equipos de investigación SEPA-interea de la Universidad de Santiago de Compostela y Política Educativa, Historia y Sociedad de la Universidad de A Coruña. 